\title{
Comparison of earthquake-triggered turbidites from the Saguenay (Eastern Canada) and Reloncavi (Chilean margin) Fjords: Implications for paleoseismicity and sedimentology
}

Guillaume St-Onge ${ }^{\mathrm{a}}$ Emmanuel Chapron $^{\underline{\mathrm{b}}}$ Sandor Mulsow $^{-\mathrm{c}}$ Marcos Salas $^{\mathrm{a}} \stackrel{\mathrm{c}}{\mathrm{c}}$ Matias Viel $^{\mathrm{c}}$ Maxime Debret ${ }^{\underline{b}, \underline{d}}$ Anthony Foucher ${ }^{\underline{b}}$ Thierry Mulder ${ }^{\mathrm{e}}$-Thierry Winiarski ${ }^{\mathrm{f}}$ Marc Desmet $^{\underline{\mathrm{b}}}$ Pedro J.M. Costa ${ }^{\underline{g}}$ Bassam Ghaleb $^{\underline{h}}$ Alain Jaouen ${ }^{\mathrm{i}}{ }^{-}$acques Locat ${ }^{\mathrm{i}}$

${ }^{a}$ Canada Research Chair in Marine Geology, Institut des sciences de la mer de Rimouski (ISMER) \& GEOTOP, 310 allée des Ursulines, Rimouski, Québec, Canada G5L 3A1

${ }^{\mathrm{b}}$ Institut des Sciences de la Terre d'Orléans, UMR 6113 CNRS, Université d'Orléans, Université François Rabelais de Tours, Observatoire des Sciences de l'Univers en région Centre, 1A rue de la Férollerie, 45071 Orléans cedex 2, France

${ }^{\mathrm{c}}$ Instituto de Geociencias, Universidad Austral de Chile, Valdivia, Chile

${ }^{\mathrm{d}}$ Laboratoire de Morphodynamique Continentale et Côtière (M2C) UMR 6143, 2-4, Rue des tilleuls, Université de Caen, Campus 1, F-14000 Caen cedex, France

${ }^{\mathrm{e}}$ Université Bordeaux 1, UMR 5805 EPOC, avenue des facultés, F-22405, Talence cedex, France

${ }^{\mathrm{f}}$ ENTPE, UMR 5023 LEHNA-IPE, Université de Lyon, Rue M. Audin, F-68518, Vaulx en Velin, France

${ }^{g}$ Centro de Geologia da Universidade de Lisboa and Departamento de Geologia, Faculdade de Ciências da Universidade de Lisboa, Edifício C6, Campo Grande, 1749-016 Lisboa, Portugal

${ }^{\text {h }}$ GEOTOP \& Université du Québec à Montréal, C.P. 8888, Succ. Centre-ville, Montréal, Québec, Canada H3C 3P8

${ }^{\mathrm{i}}$ Institut Paul-Emil Victor (IPEV), Technopole Brest-Iroise, BP 75, F-29280 Plouzné, France

${ }^{\mathrm{j}}$ Laboratoire d'études sur les risques naturels (LERN), Département de géologie et génie géologique, Université Laval, Québec, Québec, Canada G1K 7P4

\begin{abstract}
High-resolution seismic profiles along with physical and sedimentological properties of sediment cores from the Saguenay (Eastern Canada) and Reloncavi (Chile) Fjords allowed the identification of several decimeter to meter-thick turbidites. In both fjords, the turbidites were associated with large magnitude historic and pre-historic earthquakes including the $1663 \mathrm{AD}$ $(M>7)$ earthquake in the Saguenay Fjord, and the 1960 (M 9.5), $1837(M \sim 8)$ and 1575 AD major Chilean subduction earthquakes in the Reloncavi Fjord. In addition, a sand layer with
\end{abstract}


exoscopic characteristics typical of a tsunami deposit was observed immediately above the turbidite associated with the 1575 AD earthquake in the Reloncavi Fjord and supports both the chronology and the large magnitude of that historic earthquake. In the Saguenay Fjord, the earthquake-triggered turbidites are sometimes underlying a hyperpycnite associated with the rapid breaching and draining of a natural dam formed by earthquake-triggered landslides. Similar hyperpycnal floods were also recorded in historical and continental geological archives for the 1960 and 1575 AD Chilean subduction earthquakes, highlighting the risk of such flood events several weeks or months after main earthquake. In both fjords, as well as in other recently recognized earthquake-triggered turbidites, the decimeter-to meter-thick normally-graded turbidites are characterized by a homogeneous, but slightly fining upward tail. Finally, this paper also emphasizes the sensitivity of fjords to record historic and prehistoric seismicity.

Keywords : Paleoseismology; Hyperpycnites; Tsunami; Rapidly deposited layers (RDL); Submarine landslides; Active and passive margins

\section{Introduction}

Fjords are unique archives of climatic and environmental changes, but also of natural hazards (e.g., [Syvitski et al., 1987] and [Syvitski and Shaw, 1995]; see also Howe et al., 2010 for a recent compilation of papers). They can preserve thin sediment sequences deposited under very high sediment accumulation rates, making them ideally suited to record historical and pre-historical sedimentological events such as major landslides (e.g., [L'Heureux et al., 2009] and [Hansen et al., 2011]), floods (e.g., [Bornhold et al., 1994], [Urgeles et al., 2002] and [Mulder and Chapron, 2010]) or earthquakes (e.g., [Blais-Stevens and Clague, 2001], [St-Onge et al., 2004], [Chapron et al., 2006], [Dallimore et al., 2008] and [Sepulveda et al., 2010]). These types of events may trigger the deposition of rapidly deposited layers $(\mathrm{RDL})^{1}$ with specific characteristics and geometries. In fact, by carefully characterizing and dating the sediments and by comparing the basin fill seismic stratigraphy and sedimentary records with historical events, it is possible to "calibrate" the recent RDLs with a trigger mechanism and extend these observations further back in time by using seismic reflection profiles and longer sediment cores. This in turn can lead to the determination of the natural frequency of floods or the recurrence time of strong earthquakes during the last millennia, allowing to put the present changes, if any, in a longer temporal framework.

One often recorded RDL in fjord sediments are turbidites. These turbidites can either be characterized by a classical fining upward sequence (Bouma, 1962) or a sequence of reverse and normal grading, known as hyperpycnites, associated with major floods (e.g., [Mulder et al., 2003] and [Mulder and Chapron, 2010]). In geological settings with a strong historic seismicity as in active continental margins, the normally-graded turbidites are often associated with strong earthquakes (e.g., [Goldfinger et al., 2007], [Goldfinger et al., 2008], [Goldfinger, 2011], [Blumberg et al., 2008] and [Nakajima and Kanai, 2000]).

In this paper, we will compare the sedimentological properties of earthquake-triggered turbidites in fjords from a passive and an active margin: the Saguenay Ford (Eastern Canada) and Reloncavi Fjord (southern Chilean margin), respectively. While a major part of the sedimentological data from the Saguenay Fjord was previously published and used here for comparison, the Chilean data are original and discussed in detail for the first time. In both settings, we will first look at basin fill geometries and at the properties of historical events 
before extending the records further back in time using longer cores. We will reveal the similarities of the turbidites from both environments, discuss some of their implications in terms of sedimentology and paleoseismicity. Finally, the comparison between the two sites will also be used to illustrate the sensitivity of fjords to record historical and pre-historical earthquakes.

\section{Geological background}

\subsection{The Saguenay Fjord (Eastern Canada)}

The Saguenay Fjord (Québec) is a long $(90 \mathrm{~km})$ and narrow $(1-6 \mathrm{~km})$ glacially excavated valley that lies in an ancient graben in the Precambrian Canadian Shield (Fig. 1). It contains three sub-basins (inner, intermediate and outer basins) delimited by rocky sills of different water depths as shown in Fig. 2. It is adjacent to the seismically active region of Charlevoix, where five $\mathrm{M}>6$ earthquakes ( $\mathrm{M}$ is the moment magnitude) occurred during the last 350 years (Fig. 1- [Gouin, 2001] and [Lamontagne, 2009]). The Saguenay Fjord receives sediment from the Saguenay-Lac-Saint-Jean watershed $\left(78,000 \mathrm{~km}^{2}\right)$, which has a mean monthly discharge of $1500 \mathrm{~m}^{3} \mathrm{~s}^{-1}$, but can reach $5000 \mathrm{~m}^{3} \mathrm{~s}^{-1}$ during the spring freshet (Syvitski and Schafer, 1996). Average mean suspended particulate matter (SPM) concentration is $3 \mathrm{mg} \mathrm{l}^{-1}$ with a maximum of $24 \mathrm{mg} \mathrm{l}^{-1}$ (Hébert, 1995). The fjord contains a $\sim 10 \mathrm{~m}$ thick brackish (0-10) surface layer separated by a sharp pycnocline that overlies the penetrating saline (30.5) waters of the Lower St. Lawrence Estuary (Syvitski and Schafer, 1996; Fig. 2c).

Air gun seismic-reflection profiles in the Saguenay Fjord reveal a greater than 800-m-thick Quaternary sediment sequence filling the fjord and possibly reaching $1300 \mathrm{~m}$ in thickness in the intermediate basin (Praeg and Syvitski, 1991). Five seismo-stratigraphic units were identified and attributed to the advance and retreat of the Laurentide Ice Sheet (LIS) during the Late Wisconsinan or to more recent mass transport deposits ( [Syvitski and Praeg 1989] and [Syvitski and Schafer, 1996]): unit 1 is interpreted as ice-loaded glacimarine and subglacial deposits, unit 2 as ice-proximal sediments associated with rapid deposition at the margin of the LIS, unit 3 as ice-distal glacimarine sediments deposited during an elevated sea level (i.e., the Laflamme Sea) and a rapidly ablating ice sheet, unit 4 as Holocene deltaic lobes of the Saguenay delta and unit 5 as a recent turbidite.

Following deglaciation at around $10 \mathrm{kyr}$ BP (e.g., [Dionne and Occhietti, 1996] and [Occhietti et al., 2011]), saline waters of the Laflamme Sea flooded the Saguenay depression with a maximum relative sea level $198 \mathrm{~m}$ higher than present (Lasalle and Tremblay, 1978) and deposited a thick draping layer of slightly calcareous light gray clays, the Laflamme Sea clays (LSC in Fig. 2; Lasalle and Tremblay, 1978). Holocene sediments are a few meters to tens of meters in thickness in the fjord. Modern sedimentation rates range from $7 \mathrm{~cm} \mathrm{yr}^{-1}$ at the head of the fjord to less than $0.1 \mathrm{~cm} \mathrm{yr}^{-1}$ in the deepest part of the inner basin ( [Smith and Walton, 1980] and [Zhang, 2000]).

Recent multibeam surveys (Fig. 2) allowed the identification of several submarine landslides, with the largest one associated with the $\mathrm{M}>7$ earthquake of $1663 \mathrm{AD}$ (e.g., [Lévesque et al., 2006], [Locat, 2008], [Locat, 2011] and [Locat and Lévesque, 2009]). The 1663 AD earthquake generated a basin collapse: about $3 \mathrm{~km}^{3}$ of landslides and coeval submarine slides cover most of the deep basin of the fjord (Syvitski and Schafer, 1996). A landslide in the Laflamme Sea clays at the head of the fjord probably dammed the Saguenay River with about 
$0.2 \mathrm{~km}^{3}$ of material (Legget and Lasalle, 1978). Syvitski and Schafer (1996) interpreted that this dam was breached during the following spring freshet, contributing to very high SPM concentrations, which generated an estimated 28-day-long flood and a 11-day-long hyperpycnal plume (Mulder et al., 1998). These earthquake-triggered slides and the subsequent flood event lead to the deposition of a widely distributed several meter-thick turbidite characterized by an acoustically transparent facies (Unit 5) near the top of the Holocene sequence ( [Perret et al., 1995], [Syvitski and Schafer, 1996], [St-Onge et al., 2004] and [Mulder et al., 1998]). In sediment cores, the coarse base and lighter color of the turbidite contrast with the darker underlying and overlying sediments (e.g., [Syvitski and Schafer, 1996], [St-Onge and Hillaire-Marcel, 2001] and [St-Onge et al., 2004]). Syvitski and Schafer (1996) concluded that the turbidite observed in sediment cores or in high-resolution seismic reflection profiles throughout the inner basin of the fjord was deposited by this hyperpycnal flow.

\subsection{Reloncavi Fjord}

The Reloncavi Fjord is located at $41.6^{\circ} \mathrm{S}$ in the Andean Cordillera in Northern Patagonia (Chile) and is one of the most equatorial fjords in the world (Fig. 1 and Fig. 3). It is $\sim 50 \mathrm{~km}$ long, narrow $(2-5 \mathrm{~km})$ and curved: the inner basin is orientated NNE-SSW downstream from the Petrohue delta, but the intermediate basin situated between the Puelo delta and the Marimelli Island turns towards the SW, while the outer basin is connected to the West with the Reloncavi Bay (Fig. 3). This large bay corresponds to the southern prolongation of the Chilean Central Valley (CCV) developed at the piedmont of the Andes and separated from the Pacific Ocean by the Coastal Cordillera. These mountain ranges and the CCV are resulting from the subduction of the Nazca plate underneath the South America plate (Fig. 1). The development of the North Patagonian ice field in the Andes and piedmont glaciers down to the CCV during Quaternary glaciations resulted in the formation of numerous lakes, bays, and fjords following the last deglaciation ( [Laugénie, 1982], [Moreno et al., 2001], [Abarzua et al., 2004], [Kaiser et al., 2005], [Chapron et al., 2006], [Charlet et al., 2008], [Siani et al., 2010] and [Heirman et al., 2011]). The catchment area of Reloncavi Fjord $\left(11,461 \mathrm{~km}^{2}\right)$ with its highest peak at Monte Tronador (3451 m asl) includes several large glacial lakes both in Chile (lakes Todos Los Santos and Tagua Tagua) and in Argentina (lakes Mascardi and Puelo). Precipitation in the study area is essentially related to the strength (and latitude) of the westerlies bringing moisture from the Pacific Ocean, resulting in intense precipitation and favoring large mean river discharges into Reloncavi Fjord: $670 \mathrm{~m}^{3} \mathrm{~s}^{-1}$ and $278 \mathrm{~m}^{3} \mathrm{~s}^{-1}$ for Puelo and Petrohue rivers, respectively (Valle-Levinson et al., 2007). Fresh water supply together with tidal currents (up to $10 \mathrm{~cm} \mathrm{~s}^{-1}$ ) results in the formation of a pycnocline at $\sim 10 \mathrm{~m}$ of water depth.

The oblique angle associated with the subduction of an oceanic ridge (the Chilean Triple Junction) below the South America plate offshore the Taitao Peninsula forms the $\sim 1000 \mathrm{~km}$ long Liquine-Ofqui Fault Zone (LOFZ) striking NNE-SSW as shown in Fig. 1 (Thomson et al., 2001). The thirteen active volcanoes from the Southern Volcanic Zone of the Andes are located along this fault zone ( [López-Escobar et al., 1993] and [Lange et al., 2008]), such as the Yate, Calbuco and Osorno volcanoes shown in Fig. 3. The upper basin of the Reloncavi Fjord also follows the LOFZ between the Petrohue and Puelo deltas (Fig. 3). Along the LOFZ, a seismic swarm of more than 7200 earthquakes occurred in Aysen Fjord (Fig. 1) from January to June 2007 AD with magnitudes increasing from M 5.2 to 6.2. The two largest earthquakes (M 6.1 and 6.2) occurred on April 2nd and 21th 2007 AD, respectively (Legrand et al., 2011). This latest earthquake generated up to 300 landslides close to the epicenter that 
resulted in 1) a relatively thin (centimeter- to meter-scale) but very heterogeneous deposit both in space and in internal structure (Van Daele et al., 2010) and 2) a tsunami wave within the fjord (Naranjo et al., 2009). A similar phenomenon occurred in 1927 (Naranjo et al., 2009).

Five large historical subduction earthquakes affected the area (Fig. 1) in 2010 AD (M 8.8), $1960 \mathrm{AD}$ (M 9.5), $1837 \mathrm{AD}$ (estimated M of 8.0), $1737 \mathrm{AD}$ (estimated M of 7.5) and 1575 AD ( [Lomnitz, 1970], [Lomnitz, 2004], [Beck et al., 1998], [Cisternas et al., 2005] and [Horton et al., 2011]). Except for the 1737 AD event, all the other large earthquakes were associated with very long rupture zones (up to nearly $1000 \mathrm{~km}$ in 1960 AD) and were tsunamigenic. The 2010 AD Maule earthquake generated a tsunami along the adjacent Chilean coast with a maximum reported localized runup of $29 \mathrm{~m}$ on a coastal bluff at Constitución, and also resulted in a devastating inundation in the Juan Fernandez Archipelago and on Easter Island ( [Lorito et al., 2011] and [Fritz et al., 2011]), but did not trigger large submarine landslides along the Chilean coast near the epicenter (Volker et al., accepted for publication). In 1960 AD, devastating tsunami waves affected the Pacific coasts of southern Chile, Hawaii and Japan, but only smaller waves propagated eastward into the Chiloe inland Sea and adjacent bays and fjords (Chapron et al., 2006). The reported effects of the 1575 AD earthquake resembled those of $1960 \mathrm{AD}$ ( [Lomnitz, 1970] and [Cisternas et al., 2005]) and included co-seismic movements, numerous sub-aerial landslides in the Andes along the LOFZ and sub-aquatic slides and violent waves in several Chilean and Argentinean lakes ( [Veyle, 1960], [Lomnitz, 1970] and [Chapron et al., 2006]). These two major historical events also triggered eruptions of the Puyehue volcano in $1960 \mathrm{AD}$ and of the Osorno volcano in 1575 AD.

\section{Methods}

In this paper, we will present the Saguenay and Reloncavi Fjords' recent Holocene basin infill geometries combining seismic reflection, bathymetric and core data (MD99-2222, MD073108 and -3106) sampled on board the R/V Marion Dufresne II as part of the IMAGES (International Marine Past Global Change Study) program. The Calypso core MD99-2222 (38 m long) was sampled in 1999 in the inner basin of Saguenay Fjord (Eastern Canada, Fig. 2) as part of the leg 2 of the IMAGES V expedition, whereas the CASQ core MD07-3108 $\mathrm{Cq}(7.4 \mathrm{~m}$ long) and its companion surface HAPS core (MD07-3106H, $0.3 \mathrm{~m}$ long) were raised at the same coring station from the outer basin of the Reloncavi Fjord (southern Chilean margin, Fig. 3) in February 2007 as part of the IMAGES XV (PACHIDERME) expedition, prior to the 2010 M 8.8 earthquake and tsunami (e.g., [Lorito et al., 2011] and [Horton et al., 2011]) and the 2007 M 6.2 Aysen earthquake.

Seismic reflection data from the Saguenay Fjord presented in this study (Fig. 4) consist in unpublished $3.5 \mathrm{kHz}$ chirp data acquired on board R/V Marion Dufresne II in 1999 (Fig. 4d) and in previously published Huntec deep-towed system (filtered into 0.5 to $10 \mathrm{kHz}$ and 0.5 to $3 \mathrm{kHz}$ records) (Fig. 4b-c, modified from Syvitski and Schafer, 1996) and a 3.5-7 kHz source from a Raytheon PTR-106B echosounder (Locat et al., 1988; Fig. 4a, modified from Perret et al., 1995). In the Reloncavi Fjord, only Fig. 8b has been previously presented in Chapron et al. (2006) and other unpublished seismic data ( Fig. 5, Fig. 6, Fig. 7 and Fig. 8) consist of sparker ( Fig. 6 and Fig. 8a) and pinger (Fig. 7) profiles collected in 2004 on board the Chilean R/V Don Este using the Centipede sparker source $(1 \mathrm{kHz})$ and the Geoacoustics pinger source $(3.5 \mathrm{kHz}$ ) from the Renard Center of Marine Geology (Gent University, Belgium) within the framework of a collaborative project between the Universidad Austral de 
Chile (UACH, Valdivia), ETH Zurich (Switzerland) and Université d'Orléans (France). Below, we briefly describe the coring sites and analyses made on each core.

\subsection{Core MD99-2222 (Saguenay Fjord, Eastern Canada)}

Core MD99-2222 (Fig. 2) was raised from the deepest distal part of the inner basin of the Saguenay Fjord $\left(48^{\circ} 18.28\right.$ 'N, $70^{\circ} 15.44^{\prime} \mathrm{W}$, water depth $\left.271 \mathrm{~m}\right)$. Wet bulk density and lowfield volumetric magnetic susceptibility $(k)$ were measured on board using a GEOTEK MSCL (Multi Sensor Core Logger) at $2 \mathrm{~cm}$ intervals. Archived halves were then photographed, described and measured for diffuse spectral reflectance using a hand-held Minolta CM-2002 spectrophotometer $(400-700 \mathrm{~nm})$ at $5 \mathrm{~cm}$ intervals. In this paper, we use $\mathrm{L}^{*}$ which ranges from 0 (black) to 100 (white) and was previously used to identify reworked material from the Laflamme Sea clays in Saguenay Fjord sediments (St-Onge and Hillaire-Marcel, 2001).

Grain size analyses were made at the Université Bordeaux 1 with a Malvern Super sizer "S" $(0.05-754 \mu \mathrm{m})$ with a sampling interval of $\leq 1 \mathrm{~cm}$ in each RDL and at $5 \mathrm{~cm}$ intervals between the RDL. The grain size data were then processed with the Gradistat program (Blott and Pye, 2001). Only grain size data in the measured range $(0.05-754 \mu \mathrm{m})$ are presented. $\mathrm{CaCO}_{3}$ contents were analyzed with an automatic Bernard calcimeter at $10 \mathrm{~cm}$ intervals at the Université Bordeaux 1.

Paleomagnetic measurements were performed on u-channel samples in the paleomagnetism laboratory at the University of California in Davis, using a 2-G Enterprises Model 755 cryogenic magnetometer at $1 \mathrm{~cm}$ intervals. Inclinations were calculated by principal component analysis (Kirschvink, 1980) using 4 to 9 alternating field (AF) demagnetization steps at peak fields of $10-50 \mathrm{mT}$.

\subsection{Cores MD07-3108 and MD07-3106 (Reloncavi Fjord, southern Chilean margin)}

Cores MD07-3108 Cq $\left(41^{\circ} 42.01^{\prime} \mathrm{S}, 72^{\circ} 40.09^{\prime} \mathrm{W}\right.$, water depth $458 \mathrm{~m}$, CASQ corer $)$ and MD07-3106H ( $41^{\circ} 42.00^{\prime} \mathrm{S}, 72^{\circ} 40.08^{\prime} \mathrm{W}$, water depth $459 \mathrm{~m}$, HAPS surface corer) were collected at the same coring site in the distal part of the outer basin; Fig. 3. The CASQ corer is designed for the sampling of large volume cores of up to $9 \mathrm{~m}$ long with a preserved sediment/water interface, whereas the HAPS surface corer is designed to recover an intact sediment/water interface. Low-field volumetric magnetic susceptibility $(k)$ was measured on board using a point sensor on a GEOTEK MSCL (Multi Sensor Core Logger) at $2 \mathrm{~cm}$ intervals. Archived halves were also described and measured on board for spectral reflectance using a hand-held Minolta CM2600d spectrophotometer $(400-700 \mathrm{~nm})$ at $2 \mathrm{~cm}$ intervals following the protocol described in Debret et al. (2006). In this paper, we use $b^{*}$ which ranges from yellow to blue and was previously used for example to identify changes in diatom contents vs. terrestrial inputs in Saanich Inlet, a Canadian fjord (Debret et al., 2006). XRF analysis using an Innov-X scanner was also performed on u-channel samples at $1 \mathrm{~cm}$ intervals at ISMER. Even though the XRF results are presented as ppm, only relative changes are discussed as an absolute calibration with sediments was not performed. CAT-scan analysis was performed on the u-channels at INRS-ETE (Québec City). The CT numbers presented in this paper primarily reflect changes in bulk density (e.g., [St-Onge et al., 2007] and [St-Onge and Long, 2009]). The grain size measurements were made with a Beckman-Coulter LS$13320(0.04$ to $2000 \mu \mathrm{m})$ laser sizer at ISMER. The grain size data were then processed using the Gradistat software (Blott and Pye, 2001). Again, only grain size data in the measured range $(0.04$ to $2000 \mu \mathrm{m})$ are presented. 
The ${ }^{210} \mathrm{~Pb}$ measurements were made after chemical treatment, purification and deposition on a silver disk following routine procedures at GEOTOP (Zhang, 2000) by alpha counting of the daughter ${ }^{210}$ Po. Radiocarbon analysis (Table 1) was performed at the Poznan Radiocarbon Laboratory (Poland) on a wood debris sampled at $444 \mathrm{~cm}$ and on a pelecypod shell sampled at $562 \mathrm{~cm}$ (in hemipelagic sediments). The ages were calibrated with the CalPal-2007-Hulu Southern Hemisphere calibration curve (Weninger and Jöris, 2007). For the shell sample, a reservoir correction of 400 years was applied $(\Delta \mathrm{R}=0)$, as previously proposed by Kaiser et al. (2005) for the Holocene sequence of ODP site 1233 located at $41^{\circ} \mathrm{S}$ offshore Chile.

Scanning Electron Microscope (SEM) exoscopic analysis was undertaken based on the analysis of 32 quartz grains collected from the sand layer immediately above rapidly deposited layer 3 and 18 quartz grains from background sediments. The grains were randomly selected under the binocular microscope in the $125-500 \mu \mathrm{m}$ size fractions. Once images of each grain were acquired, the main microtextures (e.g. fresh surfaces, fractures, percussion marks, dissolution, angulosity and adhering particles) were classified from 0 (absent) to 5 (occupying more than 75\%) according to the area of the surface of the grain they occupied. Another classification was used, dividing the grains in 3 types: A - where dissolution dominates the surface of the grain; B - abundant presence of fresh surfaces; and C percussion marks dominate the surface of the grain ( [Costa et al., 2010] and [Costa et al., submitted for publication]). Cluster and principal component statistical analysis were conducted to assist in the characterization of the tsunamigenic layer/grains. To validate the statistical representativeness of the grain population an empirical test was conducted in a population of $\sim 150$ grains. For each sample and microtextural attribute, a global median value (medtot) was calculated using the total number of grains analyzed $(\mathrm{N})$. Next, a new set of median values (medpart) were calculated by successively increasing the number of grains involved in the computation by 1 , from 1 to $\mathrm{N}$. The results were normalized (mednorm) by subtracting each medpart from medtot. It was observed that the dispersion rapidly decreased with increasing number of grains. Taking the range of medtot \pm 0.5 as indicative of the stabilization of the median value, the minimum number of grains required in this semiquantitative approach to conduct preliminary sedimentological interpretations is 16 per sample.

\section{Results}

\subsection{Saguenay Fjord}

Four main seismic facies are identified within the previously recognized seismic units 4 and 5 (the upper $50 \mathrm{~m}$; [Praeg and Syvitski, 1991] and [Syvitski and Schafer, 1996]) of the Saguenay Fjord (Fig. 4): facies F1 and F2 within Unit 4 and facies F3 and F4 within Unit 5. Facies F1 is observed in the lower part of high-resolution seismic profiles throughout the inner basin and is characterized on high-resolution profiles by equally spaced, continuous medium to high amplitude reflections of acoustically layered sediments. They are locally interrupted by several seismically chaotic to transparent, lens-shaped bodies of variable size (facies F2), which feature a slightly hummocky top surface and possibly an erosive base. This seismic facies occurs, in particular, in the proximal part of the deep inner basin (Fig. 4a) where it exceeds $50 \mathrm{~m}$ in thickness, but quickly thins towards the East (where it reaches less than $20 \mathrm{~m}$ in thickness) and underlies a large and seismically transparent deposit (Unit 5). Facies F3 is present near the sediment/water interface in most of the inner basin and has a smooth upper limit. It reaches a thickness of $15 \mathrm{~m}$ in the deepest part of the fjord (near MD992222 coring site) and is laterally developing onlaps (Fig. 4a and b). Facies F3 is characteristic 
of large and fine-grained turbidites (Mulder and Cochonat, 1996). In the distal part of the inner basin (Fig. 4b, c and d) and along the fjord axis, the base of facies F3 is also locally characterized by a thin facies F4 composed of several high amplitude reflection of variable continuity.

High-resolution physical, magnetic, sedimentological (detailed description and grain size) and geochemical $\left(\mathrm{CaCO}_{3}\right)$ analyses revealed the presence of at least 14 RDLs in core MD99-2222 (Fig. 9), matching the occurrence of several high-amplitude reflections in facies F1. The uppermost RDL is a 15-m thick layer corresponding to facies F3 near the seabed and F4 between 13 and $16 \mathrm{~m}$ below the seafloor. This RDL has been associated with the $1663 \mathrm{AD}$ earthquake (St-Onge et al., 2004). Throughout the core these RDL are easily recognizable by their sandy bases (associated with higher values in wet bulk density and magnetic susceptibilities), light gray color, high $\mathrm{CaCO}_{3}$ content and low basal paleomagnetic inclinations, contrasting sharply with the dark gray bioturbated background sediments. The light gray color and the high $\mathrm{CaCO}_{3}$ contents indicate the incorporation of Laflamme Sea clays (St-Onge and Hillaire-Marcel, 2001), whereas the low paleomagnetic inclinations at the base of the RDL indicate an energetic depositional process, the magnetic particles being oriented horizontally because of high flow velocity and rapid sediment accumulation.

Using digital X-radiography and grain size analyses at $\leq 1 \mathrm{~cm}$ spacing, St-Onge et al. (2004) showed that six RDLs, ranging from $7 \mathrm{~cm}$ to $1 \mathrm{~m}$ in thickness (Fig. 9), are fining upward and resulted from the transformation of earthquake-triggered slumping. Their sandy bases are variable in thicknesses but are generally less sorted than their more homogenous fine tails (Fig. 10). Earthquakes that produced RDLs in the Saguenay Fjord are likely to have a magnitude higher than 6.75 (Urgeles et al., 2002) assuming that their epicenter is located near the one of the 1988 earthquake (Fig. 1), which had a magnitude of 6 and did not produce significant landslides or submarine slides in the deepest part of the inner basin ( [St-Onge and Hillaire-Marcel, 2001] and [Urgeles et al., 2002]). Small localized submarine slides possibly linked to the $1988 \mathrm{AD}$ earthquake were nonetheless observed in the Baie des Ha!Ha! or in the Northern Arm of the fjord (Lévesque et al., 2006). Six additional RDLs, ranging from $40 \mathrm{~cm}$ to $15 \mathrm{~m}$ in thickness (Fig. 9), have a similar fining upward basal unit, but are overlain by a coarsening upward unit that underlies a second fining upward unit. The two units at the top are associated with the deposition of a flood-induced hyperpycnal flow. By analogy with the 1663 event, such beds are inferred to result from the breaching and rapid draining of a natural dam generated by an earthquaketriggered landslide (see St-Onge et al., 2004 for details). Based on this interpretation, the chronology derived from paleomagnetic secular variation, relative paleointensity (St-Onge et al., 2003) and one AMS ${ }^{14} \mathrm{C}$ date, the Saguenay Fjord record contains turbidites, triggered either directly or indirectly by strong earthquakes during the last 7200 cal BP (Table 2; see St-Onge et al., 2004 for details).

\subsection{Reloncavi Fjord}

Both sparker and pinger seismic profiles in the Reloncavi Fjord are highlighting the presence of numerous mass wasting deposits (MWDs) along the slopes of the Puelo delta and in the infill of the intermediate and outer basins (Fig. 6 and Fig. 7). In the most distal part of the outer basin, these MWDs are still erosive and evolving into acoustically transparent bodies with onlapping geometries and a high amplitude reflection at their base. These acoustically transparent bodies are typical for large and fine grained turbidites ( [Mulder and Cochonat, 1996] and [Chapron et al., 2006]). Up to seven distal turbidites are identified on pinger data (Fig. 7 and Fig. 8) either stacked in front of a rock sill or in front of a $30 \mathrm{~m}$ thick acoustically layered levee (near the coring site MD07-3108Cq, labeled drift deposit on Fig. 8a). This large 
levee, observed below $450 \mathrm{~m}$ water depth at the transition from the Reloncavi Fjord to Reloncavi Bay, is suggesting strong bottom currents at the seabed (Faugères et al., 1999). These peculiar elongated and stratified deposits can be related to strong tidal currents (Bøe et al., 2000) that were previously documented in the Reloncavi Bay (Chapron, 2008), but also at several locations in Chilean fjords ( [Sievers and Silva, 2008] and [Castillo and Velenzuela, 2008]). Similar channel-levee systems were also identified on the seafloor of several gulf, channels and bays of the Chilean coast of Patagonia ( [Dasilva et al., 1997] and [Kissel and The shipboard Scientific party, 2007]). It is thus possible that the successive distal turbidites stacked in the distal part of the Reloncavi Fjord have recently filled the channel of a large drift deposit. Based on the available set of profiles in the Reloncavi Fjord, it is clear that these turbidites are originating from mass wasting events initiated along the eastern slopes of the Puelo delta that passed from the intermediate basin into the outer one through a bedrock channel located south of the Marimeli Island (Fig. 5).

As with the Saguenay Fjord core, the physical and sedimentological properties of core MD07$3108 \mathrm{Cq}$ allowed easy recognition of 4 RDLs (Fig. 11). These layers range from $219 \mathrm{~cm}$ (RDL 1) to $48 \mathrm{~cm}$ (RDL 2) in thickness and were also clearly visible on board the ship after the opening of the CASQ corer for further sampling (Fig. 12). They can easily be correlated with the four upper turbidites identified on pinger profiles (Fig. 7 and Fig. 8). The RDLs are sharply contrasting with the greenish to yellowish and bioturbated muds associated to the "continuous" background sedimentation in Chilean fjords from Northern Patagonia ( [Mulsow et al., 2009] and [Rebolledo et al., 2011]; Fig. 12). These bioturbated muds are notably characterized by higher values in $b^{*}$ due to their yellowish color (Fig. 11). The RDLs are clearly defined by a poorly sorted coarser base, a dark gray color reflected by higher $\mathrm{L}^{*}$ values (not shown) and lower b* values (Fig. 11), a higher Fe content, as a well as a fining upward trend. These data along with the visual description of the core (see Fig. 12) also reveal the similarity of these four RDLs, as well as their very homogenous upper part. These properties indicate that these 4 RDLs are classical fining upward turbidites. The increase in $\mathrm{Fe}$ content in the turbidites suggests an increase in terrestrially-derived sediments originating from the (mostly) igneous Andes mountains ( [Lamy et al., 2004] and [Muratli et al., 2010]) drained by the Puelo River (Fig. 3).

In addition, a thin sandy layer is observed immediately above RDL 3 (Fig. 13), with no hemipelagic sediments between the two layers, suggesting deposition immediately after the turbidite. Sea urchin fragments of Spatonyuide anea with preserved spines and urchin hairs were also observed in that thin layer and indicate remobilization of littoral material (sands and living organisms). Moreover, the SEM exoscopic analysis revealed that the grains from that sand layer are peculiar when compared with the background sediments (Fig. 14). The grains from the sand layer present significant fracturation (conchoidal, parallel and steps) and, in some cases, indentation (percussion marks) and sharp edges (Fig. 13). These features (more specifically their frequency, neatness and freshness) are commonly associated with strong inter-grain collisions and in association with a unique and high energy event that affected the grains immediately before deposition ( [Costa et al., 2010] and [Costa et al., submitted for publication]). The differentiation of glacial (i.e., other frequent type of grains in the study area) and tsunami grains is complex, mainly because as Mahaney (2002) stated: glacial grains present the greatest range of microtextures when compared with other grains affected by other geological agents. Nonetheless, Fig. 14 allows to distinguish grains namely by their mean and by the $1,25,75,99$ percentile microtextural values even if the global range in the classification is similar. The mean values (classification in terms of area of the surface of the grain) for the sand layer are 3, 3, 2, 2 and 1 for angulosity, fresh surfaces, v-marks, dissolution and adhering particles, respectively. By 
contrast, the mean values for the background sediments are 1, 2.5, 1, 2.5 and 3 for angulosity, fresh surfaces, percussion marks and adhering particles, respectively. Acknowledging the caution that must be taken in the interpretation, the two populations of grains can be differentiated. These results indicate that the typical sand grain in the layer above RDL 3 (e.g. Fig. 13b) is a sub-angular to angular grain mechanically marked by impact in more than $50 \%$ of its surface, but still presents some dissolution and adhering particles. The microtextures revealed in the Reloncavi Fjord sediments and their representation in the grain population have also been detected in samples associated with tsunamis from Indonesia (2004 Tsunami) and Scotland (Storegga Tsunami) (Costa et al., 2010), strongly suggesting that they were formed by a tsunami.

In order to date these turbidites, three methods were employed: 1) radiocarbon dating and 2 ${ }^{210} \mathrm{~Pb}$ measurements between the two uppermost RDLs (Fig. 11) of the CASQ core, and 3) ${ }^{210} \mathrm{~Pb}$ measurements from the top of the companion surface core (MD07-3106H; Fig. 15). As summarized in Table 1, a wood debris sampled at $444 \mathrm{~cm}$ in RDL 3 yielded a calibrated age of AD $1222 \pm 30$ while a pelecypod shell sampled at $562 \mathrm{~cm}$ in the background sediments yielded a calibrated age of $1475 \pm 30 \mathrm{cal}$ BP (AD $1475 \pm 31)$. These dates, along with the sedimentological data, indicate that RDL3 contains reworked organic material. By extrapolating a constant sedimentation rate down to the only available date in background sediments and by excluding the RDLs from calculation, making the assumption that they were deposited "instantaneously", we can calculate a sedimentation rate of $0.11 \mathrm{~cm} \mathrm{yr}^{-1}$. This rate is similar $\left(0.16 \mathrm{~cm} \mathrm{yr}^{-1}\right)$ to the one derived using ${ }^{210} \mathrm{~Pb}$ in the hemipelagic sediments of the companion surface core (MD07-3106H) sampled at the same location as the CASQ core (Fig. 15) and to the one $\left(0.14 \mathrm{~cm} \mathrm{yr}^{-1}\right)$ derived in sediments from nearby Gulf of Ancud (Rebolledo et al., 2011; see Fig. 3a for location). Using the radiocarbon-derived sedimentation rate, we can then assign ages of $\sim 1400 \mathrm{AD}, 1570 \mathrm{AD}, 1840 \mathrm{AD}, 1960 \mathrm{AD}$ respectively for RDLs 4, 3, 2 and 1. These ages are very close to the ages of three of the four major historical subduction earthquakes of 1575 AD , 1837 AD and 1960 AD (Lomnitz, 2004). In addition, even though the exponential decrease is not clearly seen likely due to biological mixing, there is a clear ${ }^{210} \mathrm{~Pb}$ activity signal (Fig. 11) between RDL 1 and RDL 2, indicating their recent deposition (cf. Mulsow et al., 2009). Very low ${ }^{210} \mathrm{~Pb}$ activity at the base of RDL1 also suggests that these sediments are reworked. Moreover, by examining the ${ }^{210} \mathrm{~Pb}$ measurements of core MD07-3106H, we can clearly identify and associate the uppermost RDL to the $1960 \mathrm{AD}$ earthquake (Fig. 15). Indeed, by extrapolating the derived sedimentation rate (Fig. 15b) obtained on that surface core to the top of the RDL ( $\sim \mathrm{cm}$ ), we can calculate an approximate age of 1957 AD. Based on this line of evidence and the very similar characteristics of the turbidites, we associate each of these turbidites with the strong subduction earthquakes of $1575 \mathrm{AD}, 1837 \mathrm{AD}$ and $1960 \mathrm{AD}$ and with an older prehistoric earthquake that struck the area around 1280-1390 AD based on the recording of a radiocarbon-dated tsunami deposit in nearby Rio Maullin estuary (see Fig. 3a for location; Cisternas et al., 2005). This age model is also strongly supported by the tsunami layer observed immediately above the turbidite associated with the $1575 \mathrm{AD}$ earthquake. Whether the tsunami was directly triggered by the earthquake or indirectly following submarine slides leading to the deposition of the turbidite is currently impossible to determine, but the earthquake, along with the one from $1960 \mathrm{AD}$, were both reported to generate a tsunami. The fact that no tsunami layer was observed above the turbidite associated with the $1960 \mathrm{AD}$ earthquake probably reflects that the 2.5 -m high tsunami waves reported offshore Castro harbor along the eastern coast of Chiloe Island (see Chapron et al., 2006 for details) were not powerful enough to significantly rework the littoral environment close to the coring site in the Reloncavi Fjord. In addition, the $1960 \mathrm{AD}$ event resulted in an abrupt change in the timing and amplitude of the tides in the Reloncavi Bay (see Chapron et al., 2006 and references therein). These changes induced by underwater co-seismic movements may have complicated the propagation of tsunami waves in the 
Reloncavi Fjord. This is also supported by the fact that no sandy layer associated with the 1960 AD tsunami, nor significant lithological changes were observed in surface sediments from the nearby Gulf of Ancud (Rebolledo et al., 2011). This suggests that the tsunami waves that impacted the Reloncavi Fjord in 1575 AD may have been higher than $2.5 \mathrm{~m}$.

\section{Discussion}

In the below section, we will first discuss the implications of the Chilean turbidite record in terms of paleoseismicity. We will then compare the turbidite records of both settings to highlight the similarities of their sedimentological records and the sensitivity of fjords to record strong seismic events.

\subsection{Implications for Chilean subduction earthquakes}

The presented record from the Reloncavi Fjord indicates that three of the four major historical subduction earthquakes were recorded, the $1737 \mathrm{AD}$ event being the one not recorded. According to historical accounts, the effects of the 1575 AD were similar to those of the 1960 AD earthquakes ( [Lomnitz, 1970] and [Cisternas et al., 2005]). For example, Cisternas et al. (2005) summarized that: "Conquistadors, at forts limited to the northern half of the 1960 rupture area, wrote of persistent marine inundation near Imperial, Valdivia and Castro that implies widespread tectonic subsidence. They also described a devastating tsunami near Valdivia". The new turbidite record and its overlying sand layer are consistent with this summary of historical accounts, both supporting the magnitude of the event and the chronology of the turbidite record. Similarly, the study of Cisternas et al. (2005), based on buried soils and sand layers from outcrops of the Rio Maullin estuary identified the 1960 and $1575 \mathrm{AD}$ earthquake-induced tsunamis, an older one between 1280 and $1390 \mathrm{AD}$, but not the 1837 and 1737 AD events. Mass wasting deposits associated with the 1960 and 1575 AD earthquakes were also recorded in nearby Lake Puyehue (see Fig. 3a for location), but not for the 1837 and 1737 AD events (Moernaut et al., 2006 and references therein). The recording of the $1837 \mathrm{AD}$ earthquake in the new turbidite record attest to the sensitivity of this fjord to capture strong subduction events that may not necessarily generate significant subsidence or tsunami wave (Cisternas et al., 2005). In addition, the absence of a turbidite associated with the $1737 \mathrm{AD}$ earthquake and of any subsidence or tsunami deposit in the nearby Maullin record (Cisternas et al., 2005), as well as the absence of mass wasting deposits in nearby Lake Puyehue (Moernaut et al., 2006) suggest that it was a weaker seismic event, as suggested by the historical archives: "the effects of the 1737 earthquake appear modest by comparison, even after allowing for a dearth of 18th-century historical records from south-central Chile" (Cisternas et al., 2005). Finally, the observation in Reloncavi Fjord of a turbidite at $\sim 1400 \mathrm{AD}$ (which corresponds to the timeframe of the tsunami deposit reported by Cisternas et al. (2005) at 1280-1390 AD) with sedimentological characteristics almost identical to the turbidites associated with the other subduction historical earthquakes supports its seismic origin, but also a strong magnitude for that seismic event as it generated subsidence, a tsunami (Cisternas et al., 2005) and a large turbidite (this study).

The recent large Chilean earthquake of 2010 AD (M 8.8) and the 2007 AD Aysen Fjord event (M 6.2) occurred after the PACHIDERME expedition that took place in February 2007 and are therefore not documented in the sediments presented in this study. In addition, the striking seismic swarm of more than 7200 earthquakes with magnitudes increasing from 5.2 to 6.2 that started on January 23 rd 2007 in the Aysen Fjord area (Fig. 1c) is not recorded in the sediment cores that were retrieved in the Reloncavi and Aysen Fjords respectively on February 16th 
and February 19-20th 2007 (Kissel and the shipboard scientific party, 2007). In the cores from Reloncavi Fjord, the 1927 AD Aysen Fjord event is not identified. It is also very unlikely that RDL in Reloncavi Fjord are resulting from landslides triggered by a local earthquake similar to the 2007 AD Aysen Fjord event since they are very different both in size and internal structures. RDL from the Reloncavi Fjord are essentially resulting from subaqueous remobilization of sediments accumulated in the Puelo Delta with high accumulation rates evolving distally into meter-thick turbidites with an acoustically transparent facies, whereas the 2007 AD Aysen Fjord event suggests a relatively thin (centimeter- to meterscale), but very heterogeneous deposit both in space and in internal structure (Van Daele et al., 2010). It is however possible that major subduction earthquakes along the Chilean coast favored co-seismic movements along the LOFZ similarly to the 1960 AD event (Chapron et al., 2006), which most likely contributed to mass wasting processes along the Puelo Delta that were recorded in the present study.

\subsection{Sedimentological implications}

The earthquake-triggered turbidites from the Saguenay and Reloncavi Fjords share several common features. First, in both settings, the decimeter- to meter-thick turbidites can easily be identified on seismic profiles and on cores by their physical and sedimentological properties. In each case, the turbidites have a distinctive color and incorporated material with a distinct geochemical signature associated with their provenance. Then, the fining upward turbidites within the same core and in both settings are very similar and are characterized by a coarse base, normal grading and a very homogenous upper part. In addition, in both cases, the earthquake had a direct and an indirect effect: a turbidite (resulting from MWDs) and tsunami layer in Reloncavi Fjord and a basal fining upward turbidite (resulting from MWDs) followed by a hyperpycnite in the Saguenay Fjord (cf. Fig. 13, Fig. 16 and Fig. 17).

As explained above, the hyperpycnal deposits observed in the Saguenay Fjord resulted from the rapid breaching and draining of natural dams created by earthquake-triggered landslides. A similar series of event was described in Lake Puyehue following the 1960 AD earthquake, where a natural dam generated by several earthquake-triggered landslides was breached, generating a hyperpycnal flow and the deposition of a hyperpycnite with a reverse and normal grading as in the Saguenay Fjord record (Chapron et al., 2007). Similarly, historical archives attest to a major flood following the catastrophic breaching of a dam at the outlet of Lake Rinihue created by earthquake-triggered landslides in 1575 AD. As summarized in [Lomnitz, 1970] and [Cisternas et al., 2005], the lake water behind the dam raised by $40 \mathrm{~cm}$ per day to amount to almost $80 \mathrm{~m}$ before being breached four months later. The subsequent flood killed more than 1200 people and induced large damages in the city of Valdivia.

On a methodological point of view, the turbidites from both the Saguenay and Reloncavi Fjords were easily identified by their physical and sedimentological properties. A similar approach was also applied along the Cascadian subduction zone and the Northern San Andreas Fault, where several turbidites could easily be identified and correlated on the basis of continuous measurements of magnetic susceptibility and density at the mouth of several submarine canyons and channels on the abyssal plain offshore Oregon and California, USA (e.g., [Goldfinger et al., 2007] and [Goldfinger et al., 2008]). These mostly decimeter-thick turbidites were generally characterized by a coarse base, normal grading and homogenous fine tail as in the fining-upward turbidites observed in the Saguenay and Reloncavi Fjords.

Similarly, Goldfinger (2011) briefly highlighted the physical properties of several earthquaketriggered turbidites along the Sumatran margin. Again, these turbidites share common features 
with the turbidites from the Saguenay and Reloncavi Fjords including a coarse base, normal grading and homogenous fine tail. In addition, the grain size in the uppermost part of most of the turbidites from the Saguenay and Reloncavi Fjords (Fig. 9, Fig. 10, Fig. 11,

Fig. 12 and Fig. 13), along with several earthquake-triggered turbidites from offshore Oregon and California, USA (e.g., [Goldfinger et al., 2007] and [Goldfinger et al., 2008]), is finer than the sediments immediately above in the background sediments, allowing the use of that observation to clearly define the upper contact of these turbidites. Similar homogenous upper part of fining upward earthquake-triggered deposits were also observed by [McHugh et al., 2006] and [Beck et al., 2007] in records from the North Anatolian Fault in the Marmara Sea (Turkey). However, it is important to note that thick homogenous intervals observed in cores from an active margin are not necessarily associated with seismic events. For example, in Effingham Inlet, a fjord from Vancouver Island in British Columbia (Canada), the homogenous beds are not associated with seismic events, but rather to coastal upwelling events that lead to the resuspension of sediments by bottom currents ( [Dallimore et al., 2005] and [Dallimore et al., 2008]). These beds were not characterized by a coarse base, nor by grading. In the same core, however, [Dallimore et al., 2005] and [Dallimore et al., 2008] recognized thin turbidites and several debris flows possibly associated with strong earthquakes. Similarly, Blais-Stevens and Clague (2001) identified several debris flows in Ocean Drilling Program (ODP Leg 169S) cores from Sannich Inlet, another fjord in BritishColumbia, that they attributed to moderate to large earthquakes. In these ODP cores, the debris flows appeared massive, but were not graded.

\subsection{Sensitivity of fjords for paleoseismology}

The paleoseismological records from offshore Oregon, California and Sumatra ( [Goldfinger et al., 2007], [Goldfinger et al., 2008] and [Goldfinger, 2011]) used the synchroneity of the correlated turbidites from different canyons or channels as the main argument for their trigger mechanism. This has the advantage of excluding turbidites generated by local submarine slides unassociated with an earthquake or by flooding, but the disadvantage of needing more ship time and cores. On the other hand, the Saguenay and Reloncavi Fjords records have the advantage of preserving a continuous record of decimeter- to meter-thick turbidites, as well as background sediments that accumulated at high sedimentation rates due to their proximal environments. These high sedimentation rates allowed the recording of historical seismic events that can then be used for "calibration" of the turbidites with a known sequence of events. The proximal location of the coring sites also allows, if any, to capture tsunami deposits such as in the case of the $1575 \mathrm{AD}$ earthquake and the subsequent tsunami. However, to record historical events, the coring site must be located in an area that has a long written history, but most importantly, the top of the sediment cores must be recovered and preserved. This is often not the case with long piston cores, but as shown here, this can be achieved by using large volume CASQ corers (Fig. 12). Once the "calibration" to the historical events is made, then longer cores can be employed to extend the paleoseismicity record further back in time. For example, as seen on the $3.5 \mathrm{kHz}$ seismic profiles of the Reloncavi Fjord (Fig. 7 and Fig. 8b), at least 3 others acoustically transparent deposits can be seen and therefore suggest the presence of older earthquake-triggered turbidites that were retrieved in the MD07-3107 Calypso core (31 m long). This giant piston core will be presented in another paper. 


\section{Conclusions}

High-resolution seismic profiles and physical and sedimentological properties of sediment cores from the Saguenay and Reloncavi Fjords allowed the identification of several decimeter to meter-thick turbidites. In both fjords, the turbidites were associated with large magnitude historic and pre-historic earthquakes including the $1663 \mathrm{AD}(\mathrm{M}>7)$ earthquake in the Saguenay Fjord and the 1960 (M 9.5), 1837 (estimated M of 8), 1575 AD major subduction earthquakes in the Reloncavi Fjord. These turbidites are characterized by a homogenous, but slightly fining upward tail. In addition, a sand layer associated with a tsunami was overlying the 1575 AD turbidite. In the Saguenay Fjord, the earthquake-triggered turbidites are sometimes underlying a hyperpycnal deposit associated with the rapid breaching and draining of a natural dam formed by earthquake-triggered landslides. Similar hyperpycnal floods were also recorded in historical and continental geological archives for the 1960 and 1575 AD Chilean earthquakes, highlighting the risk of such flood events several weeks or months after main earthquake. Following a strong earthquake, the head of the fjord can eventually be exposed to catastrophic hyperpycnal floods when landslides also occur in the catchment area. The presence of active faults and/or the proximity of a well-documented historic seismicity and the Quaternary geology (glacio-isostatic rebound, high sedimentation rates, quick clays in the Saguenay Fjord (Locat et al., 1984), volcanic activity and deposits in Northern Patagonia (thick Andosols, Chapron et al., 2007)) are preconditioning factors to the occurrence of landslides across tributaries and subsequent catastrophic outburst floods.

In both fjords, the high sedimentation rates between each RDL allows the recording of most of the strong seismic events compared to the margin sedimentary record, which for example, did not record the 1837 and 1737 AD events (Cisternas et al., 2005) or any major submarine landslides in the epicentral area of the 2010 AD (M 8.8) Chilean earthquake (Volker et al., accepted for publication). The presented comparison between the sedimentological records from a passive (Saguenay Fjord) and an active (Reloncavi Fjord) margin highlights that, when carefully chosen, fjords with high sediment accumulation rates are pristine sites to record historical and pre-historical earthquakes. Finally, the sedimentary record from Reloncavi Fjord also illustrates that the occurrence of several sub basins and sills is not necessarily preventing the development of mass wasting events into debris flows and large turbidites in the distal sub basins of fjords, when the sub basins are characterized by increasing depths and when the fjord is not too elongated $(<50 \mathrm{~km})$.

\section{Acknowledgments}

We are indebted to the IPEV and especially to Y. Balut in 1999 and H. Leau in 2007, the captain, officers, crew and scientific participants of the leg 2 of the IMAGES V and IMAGES XV (PACHIDERME) cruises on board the R/V Marion Dufresne II. We also thank C. Hillaire-Marcel (GEOTOP) and J.-L. Turon (U. Bordeaux I; Co-chief scientists of the leg 2 of the IMAGES V expedition), C. Kissel (LSCE, Chief scientist of the PACHIDERME cruise), K. De Rycker (RCMG), A. Abarzua (UACH; RCMG), the captain and crew of the R/V Don Este for their contribution to data collection in the Reloncavi Fjord. We thank David J.W. Piper (NRCan) for his comments on a previous draft of the manuscript, as well as the two anonymous reviewers and the journal Editor, Jasper Knight, for very constructive comments. G. St-Onge and J. Locat acknowledges support from NSERC (Discovery and Ship time grants). S. Mulsow acknowledges support from FONDECYT grant 1050247 for funding participation to the R/V Marion Dufresne II expedition and ship time on board the R/V Don 
Este (Chile survey). Part of this work was possible though a Foreign Affairs and International Trade Canada scholarship to M. Salas.

\section{References}

Abarzua et al., 2004 A.M. Abarzua, C. Villagran, P.I. Moreno Deglacial and postglacial climate history in east-central Isla Grande de Chiloé, southern Chile $\left(43^{\circ} \mathrm{S}\right)$ Quaternary Research, 62 (2004), pp. 49-59

Beck et al., 2007 C. Beck, B. Mercier de Lepinay, J.L. Schneider, M. Cremer, N. Cagatay, E. Wendenbaum, S. Boutareaud, G. Menot, S. Schmidt, O. Weber, K. Eris, R. Armijo, B. Meyer, N. Pondard, M.A. Gutscher, J.L. Turon, L. Labeyrie, E. Cortijo, Y. Gallet, H. Bouquerel, N. Gorur, A. Gervais, M.H. Castera, L. Londeix, A. de Resseguier, A. Jaouen Late Quaternary co-seismic sedimentation in the Sea of Marmara's deep basins Sedimentary Geology, 199 (2007), pp. 65-89

Beck et al., 1998 S. Beck, S. Barrientos, E. Kausel, M. Reyes Source characteristics of historic earthquakes along the central Chile subduction zone Journal of South American Earth Sciences, 11 (1998), pp. 115-129

Blais-Stevens and Clague, 2001 A. Blais-Stevens, J.J. Clague Paleoseismic signature in late Holocene sediment cores from Saanich Inlet, British Columbia Marine Geology, 175 (2001), pp. 131-148

Blott and Pye, 2001 S.J. Blott, K. Pye Gradistat: a grain size distribution and statistics package for the analysis of unconsolidated sediments Earth Surface Processes and Landforms, 26 (2001), pp. 1237-1248

Blumberg et al., 2008 S. Blumberg, F. Lamy, H.W. Arz, H.P. Echtler, M. Wiedicke, G.H. Haug, O. Oncken Turbiditic trench deposits at the South-Chilean active margin: a Pleistocene-Holocene record of climate and tectonics Earth and Planetary Science Letters, 268 (2008), pp. 526-539

Bøe et al., 2000 R. Bøe, M. Hovland, A. Instanes, L. Rise, S. Vasshus Submarine slide scars and mass movements in Karmsundet and Skudenesfjorden, southwestern Norway: morphology and evolution Marine Geology, 167 (2000), pp. 147-165

Bornhold et al., 1994 B. Bornhold, P. Ren, D.B. Prior High-frequency turbidity currents in British Columbia fjords Geo-Marine Letters, 14 (1994), pp. 238-243

Bouma, 1962 A.H. Bouma Sedimentology of Some Flysch Deposits. A Graphic Approach to Facies Interpretation Elsevier, Amsterdam (1962)

Castillo and Velenzuela, 2008 M. Castillo, C. Velenzuela Circulation regime in the austral Chilean channels and fjords N. Silva, S. Palma (Eds.), Progress in the Oceanographic knowledge of Chilean Interior waters, from Puerto Montt to Cape Horn. Comité Oceanográfico Nacional-Pontificia Universidad Católica de Valparaíso, Valparaíso, Chile (2008), pp. 59-62 
Chapron, 2008 E. Chapron Apports de la limnogéologie à la reconstitution des changements environnementaux Habilitation à Diriger des Recherches, Université d'Orléans, vol. 1 (2008) 108 p

Chapron et al., 2007 E. Chapron, E. Juvigné, S. Mulsow, D. Ariztegui, O. Magand, S. Bertrand, M. Pino, O. Chapron Recent clastic sedimentation in Lake Puyehue (Chilean Lake District, $40.5^{\circ} \mathrm{S}$ ) Sedimentary Geology, 201 (2007), pp. 365-385

Chapron et al., 2006 E. Chapron, D. Ariztegui, S. Mulsow, G. Villarosa, M. Pino, V. Outes, E. Juviginé, E. Crivelli Impact of 1960 major subduction earthquake in Northern Patagonia (Chile, Argentina) Quaternary International, 158 (2006), pp. 58-71

Charlet et al., 2008 F. Charlet, M. De Batist, E. Chapron, S. Bertrand, M. Pino, R. Urrutia Seismic stratigraphy of Lago Puyehue (Chilean Lake District): new views on its deglacial and Holocene evolution Journal of Paleolimnology, 39 (2008), pp. 163-177

Cisternas et al., 2005 M. Cisternas, B.F. Atwater, F. Torrejon, Y. Sawai, G. Machuca, M. Lagos, A. Eipert, C. Youlton, I. Salgado, T. Kamataki, M. Shishikura, C.P. Rajendran, J.J. Malik, Y. Rizal, M. Husni Predecessors of the giant 1960 Chile earthquake Nature, 437 (2005), pp. 404-407

Costa et al., submitted for publication Costa, P. J. M., Andrade, C., Dawson, A. G. Mahaney, W. C., Freitas, M. C., Paris, R., Taborda, R. submitted for publication. Exoscopic characteristics of tsunami and storm deposits. Sedimentary Geology.

Costa et al., 2010 P.J.M. Costa, C. Andrade, A.G. Dawson, M.C. Freitas, W.C. Mahaney, R. Paris, R. Taborda Exoscopic analysis in tsunamites Abstract Volume - 18th Sedimentological Congress (2010), p. 268

Dallimore et al., 2008 A. Dallimore, R.J. Enkin, R. Peinitz, J.R. Southon, J. Baker, C.A. Wright, T.F. Pedersen, S.E. Calvert, R.E. Thomson Post-glacial evolution of a Pacific coastal fjord in British Columbia, Canada: interactions of sea-level change, crustal response and environmental fluctuations; results from MONA core MD02-2494 Canadian Journal of Earth Sciences, 45 (2008), pp. 1345-1362

Dallimore et al., 2005 A. Dallimore, R.E. Thomson, M.A. Bertram Modern to Late Holocene deposition in an anoxic fjord on the west coast of Canada: implications for regional oceanography, climate and paleoseismic history Marine Geology, 219 (2005), pp. 47-69

Dasilva et al., 1997 J. Dasilva, J. Anderson, J. Stravers Seismic facies changes along a nearly continuous $24^{\circ}$ latitudinal transect: the fjords of Chile and the northern Antarctic Peninsula Marine Geology, 143 (1997), pp. 103-123

Debret et al., 2006 M. Debret, M. Desmet, W. Balsam, Y. Copard, P. Francus, C. Laj Spectrophotometer analysis of Holocene sediment from an anoxic fjord: Saanich Inlet, British Columbia, Canada Marine Geology, 229 (2006), pp. 15-18

Dionne and Occhietti, 1996 J.-C. Dionne, S. Occhietti Aperçu du Quaternaire à l'embouchure du Saguenay, Québec Géographie Physique et Quaternaire, 50 (1996), pp. 5-34 
Faugères et al., 1999 J.C. Faugères, D.A.V. Stow, P. Imbert, A. Viana Seismic features diagnostic of contourite drifts Marine Geology, 162 (1999), pp. 1-38

Fritz et al., 2011 H.M. Fritz, C. Petroff, P.A. Catalán, R. Cienfuegos, P. Winkler, N. Kalligeris, R. Weiss, S.E. Barrientos, G. Meneses, C. Valderas-Bermejo, C. Ebeling, A. Papadopoulos, M. Contreras, R. Almar, J.C. Dominguez, C.E. Synolakis Field survey of the 27 February 2010 Chile Tsunami Pure and Applied Geophysics (2011) http://dx.doi.org/10.1007/s00024-011-0283-5

Goldfinger, 2011 C. Goldfinger Submarine paleoseismology based on turbidite records Annual Review of Marine Science, 3 (2011), pp. 35-66

Goldfinger et al., 2008 C. Goldfinger, K. Grijalva, R. Burgmann, A.E. Morey, J.E. Johnson, C.H. Nelson, J. Gutierrez-Pastor, E. Karabanov, J.D. Chaytor, J. Patton, E. Gracia Late Holocene rupture of the Northern San Andreas Fault and possible stress linkage to the Cascadia Subduction Zone Bulletin of the Seismological Society of America, 98 (2008), pp. 861-889

Goldfinger et al., 2007 C. Goldfinger, A.E. Morey, C.H. Nelson, J. Gutiérrez-Pastor, J.E. Johnson, E. Karabanov, J. Chaytor, A. Ericsson, shipboard scientific party Rupture lengths and temporal history of significant earthquakes on the Offshore and Northcoast segments of the Northern San Andreas Fault based on turbidite stratigraphy Earth and Planetary Science Letters, 254 (2007), pp. 9-27

Gouin, 2001 P. Gouin Tremblements de terre «historiques» au Québec (de 1534 à mars 1925) identifiés et interprétés à partir des textes originaux contemporains ("Historical» earthquakes felt in Québec (from 1534 to March 1925) as revealed by the local contemporary literature) Guérin, Montreal (2001) 1491 p

Hansen et al., 2011 L. Hansen, J.-S. L'Heureux, O. Longva Turbiditic, clay-rich event beds in fjord-marine deposits caused by landslides in emerging clay deposits paleoenvironmental interpretation and role for submarine mass-wasting Sedimentology, 58 (2011), pp. 890-915

Hébert, 1995 S. Hébert Qualité des eaux du Saguenay-Lac-Saint-Jean. 1979-1992 Ministère de l'Environnement et de la Faune. Québec (1995) 58 pp.

Heirman et al., 2011 K. Heirman, M. De Batist, F. Charlet, J. Moernaut, E. Chapron, R. Brummer, M. Pino, R. Urrutia Detailed seismic stratigraphy of Lago Puyehue: implications for the mode and timing of glacier retreat in the Chilean Lake District Journal of Quaternary Science, 26 (2011), pp. 665-674

Horton et al., 2011 B.P. Horton, Y. Sawai, A.D. Hawkes, R.C. Witter Sedimentology and paleontology of a tsunami deposit accompanying the great Chilean earthquake of February 2010 Marine Micropaleontology, 79 (2011), pp. 132-138

Howe et al., 2010 Fjord Systems and Archives ,in: J.A. Howe, W.E.N. Austin, M. Forwick, M. Paetzel (Eds.), Special Publications, 344 Geological Society, London (2010) 
Kaiser et al., 2005

J. Kaiser, F. Lamy, D. Hebbeln A 70-kyr sea surface temperature record off southern Chile (ODP Site 1233) Paleoceanography, 20 (2005) http://dx.doi.org/10.1029/2005PA001146

Kirschvink, 1980 J.L. Kirschvink The least-squares line and plane and the analysis of paleomagnetic data Geophysical Journal of the Royal Astronomical Society, 62 (1980), pp. $699-718$

Kissel and The shipboard Scientific party, 2007 Kissel, C., The shipboard Scientific party, 2007. MD159-PACHIDERME-IMAGES VX, cruise report. Les rapports de campagne à la mer. Réf. OCE/2007/01, Institut polaire français Paul-Emile Victor, ed., Plouzané, France.

Lange et al., 2008 D. Lange, J. Cembrano, A. Rietbrock, C. Haberland, T. Dahm, K. Bataille First seismic record of intra-arc strike-slip tectonics along the Liquiñe-Ofqui fault zone at the obliquely convergent plate margin of the southern Andes Tectonophysics, 455 (2008), pp. 14-24

L'Heureux et al., 2009 J.-S. L'Heureux, L. Hansen, O. Longva Development of the submarine channel in front of the Nidelva River, Trondheimsfjorden, Norway Marine Geology, 260 (2009), pp. 30-44

Lamontagne, 2009 M. Lamontagne Possible earthquake triggers of submarine landslides in the estuary of the St. Lawrence River: insights from the earthquake catalogue Geological Survey of Canada (2009) Open file 6007, 61 pp.

Lamy et al., 2004 F. Lamy, J. Kaiser, U. Ninemmann, D. Hebbeln, H. Arz, J. Stoner Antarctic timing of surface sea water changes off Chile and Patagonian ice-sheet response Science, 304 (2004), pp. 1959-1962

Lasalle and Tremblay, 1978 P. Lasalle, G. Tremblay Dépôts meubles Saguenay Lac SaintJean. Rapport 191 Ministère des Richesses naturelles du Québec, Québec city, Québec (1978) $61 \mathrm{pp}$.

Laugénie, 1982 Laugénie, C., 1982. La Région des Lacs, Chili méridional, recherches sur l'évolution géomorphologique d'un piedmont glaciaire quaternaire andin. Habilitation Thesis, Université de Bordeaux III, vol. 1 \& 2, 822 p.

Legget and Lasalle, 1978 R.F. Legget, P. Lasalle Soil studies at Shipshaw, Quebec: 1941 and 1969 Canadian Geotechnical Journal, 15 (1978), pp. 556-564

Legrand et al., 2011 D. Legrand, S. Barrientos, K. Bataille, J. Cembrano, A. Pavez The Fluid-driven tectonic swarm of Aysen Fjord, Chile (2007) associated with two earthquakes ( $\mathrm{Mw}=6.1$ and $\mathrm{Mw}=6.2)$ within the Liquine-Ofqui Fault Zone Continental Shelf Research, 31 (2011), pp. 154-161

Lévesque et al., 2006 C. Lévesque, J. Locat, S. Leroueuil Dating submarine mass movements triggered by earthquakes in the Upper Saguenay Fjord, Quebec, Canada Norwegian Journal of Geology, 86 (2006), pp. 231-242 
Locat, 2011 J. Locat La localisation et la magnitude du séisme du 5 février 1663 (Charlevoix) revues à l'aide des mouvements de terrain Journal canadien de géotechnique, 48 (2011), pp. 1266-1286

Locat and Lévesque, 2009 J. Locat, C. Lévesque Le fjord du Saguenay: une physiographie et un registre exceptionnels Revue des sciences de l'eau, 22 (2009), pp. 135-157

Locat, $2008 \mathrm{~J}$. Locat Localisation et magnitude du séisme du 5 février 1663 (Québec) revues à l'aide des mouvements de terrain J. Locat, D. Perret, D. Turmel, D. Demers, S. Leroueil (Eds.), Proceedings of the 4th Canadian Conference on Geohazards: From Causes to Management, Presse de l'Université Laval, Québec (2008)

Locat et al., 1988 J. Locat, C.T. Schafer, M. Choquette, G. Lortie, M. Bergeron, D. Perret, M. Laroche, B. Van Havre, J.-F. Paradis Rapport de l'expédition géotechnique et géophysique 88-09 sur le fjord du Saguenay et le St-Laurent à bord du Louis M Lauzier. Report GGL-88-09. Department of Geology, Laval University (1988) 27 p.

Locat et al., 1984 J. Locat, G. Lefebvre, G. Ballivy Mineralogy, chemistry, and physical properties interrelationships of some sensitive clays from Eastern Canada Canadian Geotechnical Journal, 21 (1984), pp. 530-540

Lomnitz, 2004 C. Lomnitz Major earthquakes of Chile: a historical survey, 1535-1960 Seismological Research Letters, 75 (2004), pp. 368-378

Lomnitz, 1970 C. Lomnitz Major earthquakes and tsunamis in Chile during the period 1535 to 1955 Geologische Rundschau, 59 (1970), pp. 938-960

López-Escobar et al., 1993 L. López-Escobar, J. Cembrano, H. Moreno Geochemistry and tectonics of the Chilean southern Andes Quaternary volcanism $\left(37^{\circ}-46^{\circ} \mathrm{S}\right)$ Revista Geológica de Chile, 22 (1993), pp. 219-234

Lorito et al., 2011 S. Lorito, F. Romano, S. Atzori, X. Tong, A. Avallone, J. McCloskey, M. Cocco, E. Boschi, A. Piatanesi Limited overlap between the seismic gap and coseismic slip of the great 2010 Chile earthquake Nature Geoscience, 4 (2011), pp. 173-177

Mahaney, 2002 W.C. Mahaney Atlas of Sand Grain Surface Textures and Applications Oxford University Press (2002) 237 pp

McHugh et al., 2006 C.M.G. McHugh, L. Seeber, M.-H. Cormier, J. Dutton, N. Cagatay, A. Polonia, W.B.F. Ryan, N. Gorur Submarine earthquake geology along the North Anatolia Fault in the Marmara Sea, Turkey: a model for transform basin sedimentation Earth and Planetary Science Letters, 248 (2006), pp. 661-684

Moernaut et al., 2006 J. Moernaut, M. De Batist, F. Charlet, K. Heirman, E. Chapron, M. Pino, R. Brümmer, R. Urrutia Giant earthquakes in South-Central Chile revealed by Holocene mass-wasting events in Lake Puyehue Sedimentary Geology, 195 (2006), pp. 121-135

Moreno et al., 2001 P.I. Moreno, G.I. Jacobson, T.V. Lowell, G.H. Denton Interhemispheric climate links revealed from a late-glacial cool episode in southern Chile Nature, 409 (2001), pp. 804-808 
Mulder and Chapron, 2010 T. Mulder, E. Chapron Flood deposits in continental and marine environments: character and significance ,in: R.M. Slatt, C. Zavala (Eds.), AAPG Studies in Geology, 61 (2010), pp. 1-30

Mulder et al., 2003 T. Mulder, J.P.M. Syvitski, S. Migeon, J.-C. Faugères, B. Savoye Marine hyperpycnal flows: initiation, behavior and related deposits A review. Marine and Petroleum Geology, 20 (2003), pp. 861-882

Mulder and Cochonat, 1996 T. Mulder, P. Cochonat Classification of offshore mass movements Journal of Sedimentary Geology, 66 (1996), pp. 43-57

Mulder et al., 1998 T. Mulder, J.P.M. Syvitski, K.I. Skene Modeling of erosion and deposition by turbidity currents generated at river mouths Journal of Sedimentary Research, 68 (1998), pp. 124-137

Mulsow et al., 2009 S. Mulsow, E. Piovano, F. Cordoba Recent aquatic ecosystem response to environmental events revealed from ${ }^{210} \mathrm{~Pb}$ sediment profiles Marine Pollution Bulletin, 59 (2009), pp. 175-181

Muratli et al., 2010 J.E. Muratli, Z. Chase, J. McManus, A. Mix Ice-sheet control of continental erosion in central and southern Chile $\left(36^{\circ}-41^{\circ} \mathrm{S}\right)$ over the last 30,000 years Quaternary Science Reviews, 29 (2010), pp. 3230-3239

Nakajima and Kanai, 2000 T. Nakajima, Y. Kanai Sedimentary features of seismoturbidites triggered by the 1983 and older historical earthquakes in the eastern margin of the Japan Sea Sedimentary Geology, 135 (2000), pp. 1-19

Naranjo et al., 2009 J.A. Naranjo, M. Arenas, J. Clavero, O. Muñoz Mass movementinduced tsunamis: main effects during the Patagonian Fjordland seismic crisis in Aisén

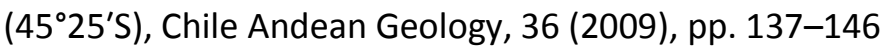

Occhietti et al., 2011 S. Occhietti, M. Parent, P. Lajeunesse, F. Robert, E. Govare Late Pleistocene-Early Holocene decay of the Laurentide Ice Sheet in Québec-Labrador, in: J. Ehlers, P.L. Gibbard (Eds.), Quaternary Glaciations - Extent and Chronology: Part IV: A closer look, Developments in Quaternary Sciences, 15, Elsevier (2011), pp. 601-630

Perret et al., 1995 D. Perret, J. Locat, S. Leroueil Strength development with burial in fine-grained sediments from the Saguenay Fjord, Quebec Canadian Geotechnical Journal, 32 (1995), pp. 247-262

Praeg and Syvitski, 1991 D.B. Praeg, J.P.M. Syvitski Marine Geology of Saguenay Fjord. Geological Survey of Canada (1991) Open File 2395, 14 sheets.

Rebolledo et al., 2011 L. Rebolledo, H.E. Gonzalez, P. Munoz, J.L. Iriarte, C.B. Lange, S. Pantoja, M. Salamanca Siliceous productivity changes in Gulf of Ancud sediments ( $42^{\circ} \mathrm{S}$, $72^{\circ} \mathrm{W}$ ), southern Chile, over the last 150 years Continental Shelf Research, 31 (2011), pp. 356-365

Sepulveda et al., 2010 S.A. Sepulveda, A. Serey, M. Lara, A. Pavez, S. Rebolledo Landslides induced by the April 2007 Aysen Fjord earthquake, Chilean Patagonia Landslides, 7 (2010), pp. 483-492 
Siani et al., 2010 G. Siani, C. Colin, E. Michel, M. Carel, T. Richter, C. Kissel, F. Dewilde Late Glacial to Holocene terrigenous sediment record in the Northern Patagonian margin: paleoclimate implications Palaeogeography, Palaeoclimatology, Palaeoecology, 297 (2010), pp. 26-36

Sievers and Silva, 2008 H.A. Sievers, N. Silva Water masses and circulation in austral Chilean channels and fjords. Progress in the Oceanographic knowledge of Chilean Interior waters, from Puerto Montt to Cape Horn N. Silva, S. Palma (Eds.), Comité Oceanográfico Nacional-Pontificia Universidad Católica de Valparaíso, Valparaíso, Chile (2008), pp. 5358

Smith and Walton, 1980 J.N. Smith, A. Walton Sediment accumulation rates and geochronologies measured in the Saguenay Fjord using $\mathrm{Pb}-210$ dating methodGeochimica et Cosmochimica Acta, 44 (1980), pp. 225-240

St-Onge and Long, 2009 G. St-Onge, B. Long CAT-scan analysis of sedimentary sequences: an ultrahigh-resolution paleoclimatic tool Engineering Geology, 103 (2009), pp. 127-133

St-Onge et al., 2007 G. St-Onge, T. Mulder, P. Francus, B. Long Continuous physical properties of cored marine sediments C. Hillaire-Marcel, A. de Vernal (Eds.), Proxies in Late Cenozoic Paleoceanography, Elsevier (2007), pp. 63-98

St-Onge et al., 2004 G. St-Onge, T. Mulder, D.J.W. Piper, C. Hillaire-Marcel, J.S. Stoner Earthquake and flood-induced turbidites in the Saguenay Fjord (Québec): a Holocene paleoseismicity record Quaternary Science Reviews, 23 (2004), pp. 283-294

St-Onge et al., 2003 G. St-Onge, J.S. Stoner, C. Hillaire-Marcel Holocene paleomagnetic records from the St. Lawrence Estuary, Eastern Canada: centennial to millennial-scale geomagnetic modulation of cosmogenic isotopes Earth and Planetary Science Letters, 209 (2003), pp. 113-130

St-Onge and Hillaire-Marcel, 2001 G. St-Onge, C. Hillaire-Marcel Isotopic constraints of sedimentary inputs and organic carbon burial rates in the Saguenay Fjord, Quebec Marine Geology, 176 (2001), pp. 1-22

Syvitski and Praeg 1989 J.P.M. Syvitski, D.B. Praeg Quaternary sedimentation in the St. Lawrence Estuary and adjoining areas, Eastern Canada: an overview based on highresolution seismo-stratigraphy Geographie Physique et Quaternaire, 43 (1989), pp. 291310

Syvitski and Schafer, 1996 J.P.M. Syvitski, C.T. Schafer Evidence for earthquake-triggered basin collapse in Saguenay Fjord, Canada Sedimentary Geology, 104 (1996), pp. 127-153

Syvitski and Shaw, 1995 J.P.M. Syvitski, J. Shaw Sedimentology and geomorphology of fjords, in: G.M.E. Perillo (Ed.), Geomorphology and Sedimentology of Estuaries, Developments in Sedimentology, 53, Elsevier (1995), pp. 113-178

Syvitski et al., 1987 J.P.M. Syvitski, D.C. Burrell, J.M. Skei (Eds.), Fjords: Processes \& Products, Springer-Verlag, N.Y. (1987) 379 pp 
Thomson et al., 2001 S.N. Thomson, F. Hervé, B. Stockhert Mesozoic-Cenozoic denudation history of the Patagonian Andes (southern Chile) and its correlation to different subduction processes Tectonics, 20 (2001), pp. 113-178

Urgeles et al., 2002 R. Urgeles, J. Locat, H.J. Lee, F. Martin The Saguenay Fjord, Quebec, Canada: integrating marine geotechnical and geophysical data for seismic slope stability and hazard assessment Marine Geology, 185 (2002), pp. 319-340

Van Daele et al., 2010 M. Van Daele, M. Debatist, W. Verstteeg, K. De Ryker, V. Cnudde, R. Gieles, P. Duyck, M. Pino, R. Urrutia Sedimentary imprint of the 2007 Aysen earthquake and tsunami in Aysen Fjord (Chilean Patagonia) Bolletino di Geofisica, 51 (2010), pp. 194-196 supp.,

Valle-Levinson et al., 2007 A. Valle-Levinson, N. Sarkar, R. Sanay, D. Soto, J. León Spatial structure of hydrography and flow in a Chilean Fjord, Estuario Reloncavi Estuaries and Coasts, 30 (2007), pp. 113-126

Veyle, 1960 C. Veyle Los fenómenos volcanicos u sismicos de fines de Mayo de 1960 en el sur de Chile Reports from Instituto Central de Quimica, University of Concepción (1960) $42 \mathrm{p}$.

Volker et al., accepted for publication Volker, D., Scholz, F., Geersen, J., accepted for publication. Analysis of submarine landsliding in the rupture area of the 27 February 2010 Maule earthquake, Central Chile. Marine Geology.

Weninger and Jöris, $2007 \mathrm{~B}$. Weninger, O. Jöris $\mathrm{A}^{14} \mathrm{C}$ calibration curve for the last $60 \mathrm{ka}$ : the Greenland-Hulu U/Th timescale and its impact on understanding the Middle to Upper Paleolithic transition in Western Eurasia Journal of Human Evolution, 55 (2007), pp. 772-781

Zhang, 2000 Zhang, D., 2000. Flux de radio-isotopes à courte période dans les bassins marins marginaux de l'est canadien. Ph.D. thesis, Université du Québec à Montréal, Montréal, Québec, 193 pp. 
Figures
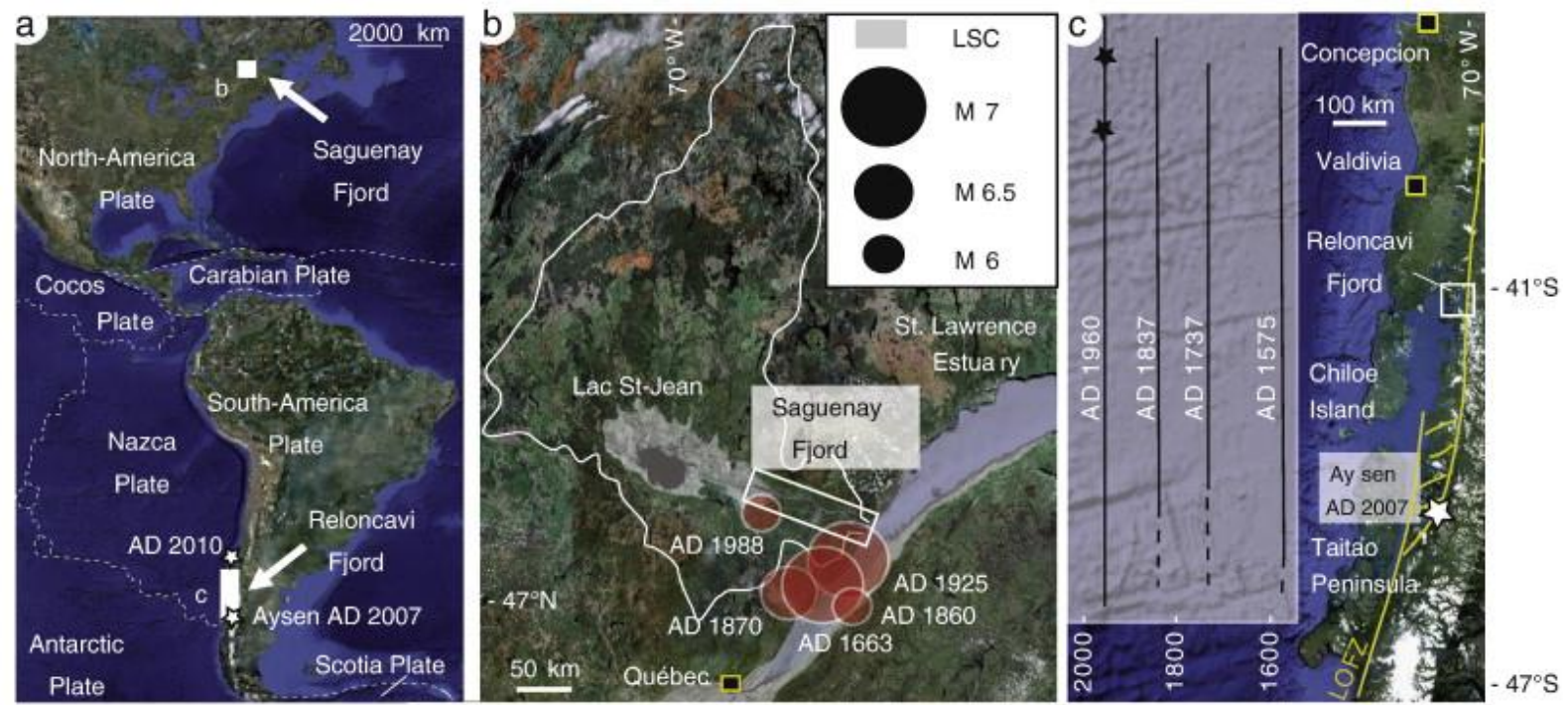

Fig. 1. General location of the studied fjords in Eastern Canada (Saguenay Fjord) and Southern Chile (Reloncavi Fjord) highlighting their contrasted geodynamic settings (a): a passive margin in Canada, but an active subduction margin in Chile. (b) Extension of the Laflamme Sea clays (LSC) in the catchment area (gray shaded area around Lac St-Jean and the Saguenay Fjord) of the Saguenay River and Fjord. The epicenters and estimated magnitudes of historical earthquakes that affected the study area are also indicated (after Lamontagne, 2009). (c) Schematic overview of the rupture zones (after Blumberg et al., 2008) associated with historical major subduction earthquakes in Southern Chile (black lines). Also illustrated (in c) are the location of the Liquiñe-Ofqui Fault Zone (LOFZ) in Northern Patagonia, the two main epicenters in 1960 AD (black stars) offshore the cities of Conception and Valdivia, and the epicenter of the 2007 AD (M 6.2) Aysen earthquake. The epicenter of the 2010 AD Chilean earthquake (M 8.8) is illustrated in a. 

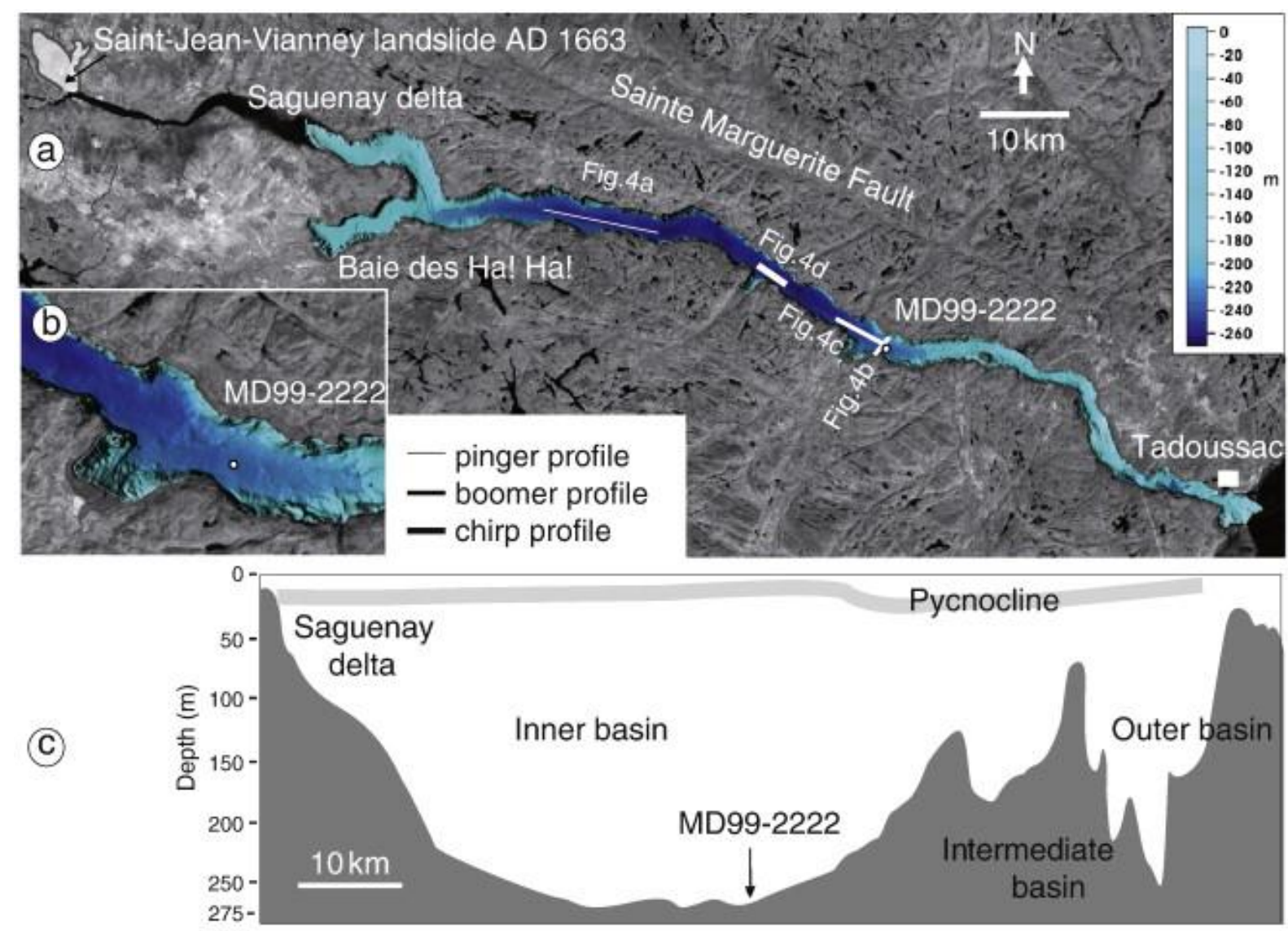

Fig. 2. a) Satellite image of the Saguenay Fjord area illustrating the proximity of faults and of the StJean-Vianney landslide (1663 AD; after Locat, 2008). The fjord multibeam bathymetry (after Locat and Levesque, 2009) is also presented together with the location of seismic profiles presented in Fig. 4 and MD99-2222 coring site. b) Zoom near the coring site. c) A bathymetric profile along the entire length of the fjord illustrates the presence of sub-basins and sills, the approximate depth of the pycnocline in the fjord waters (after St-Onge et al., 2004) and core MD99-2222 sampling site. 


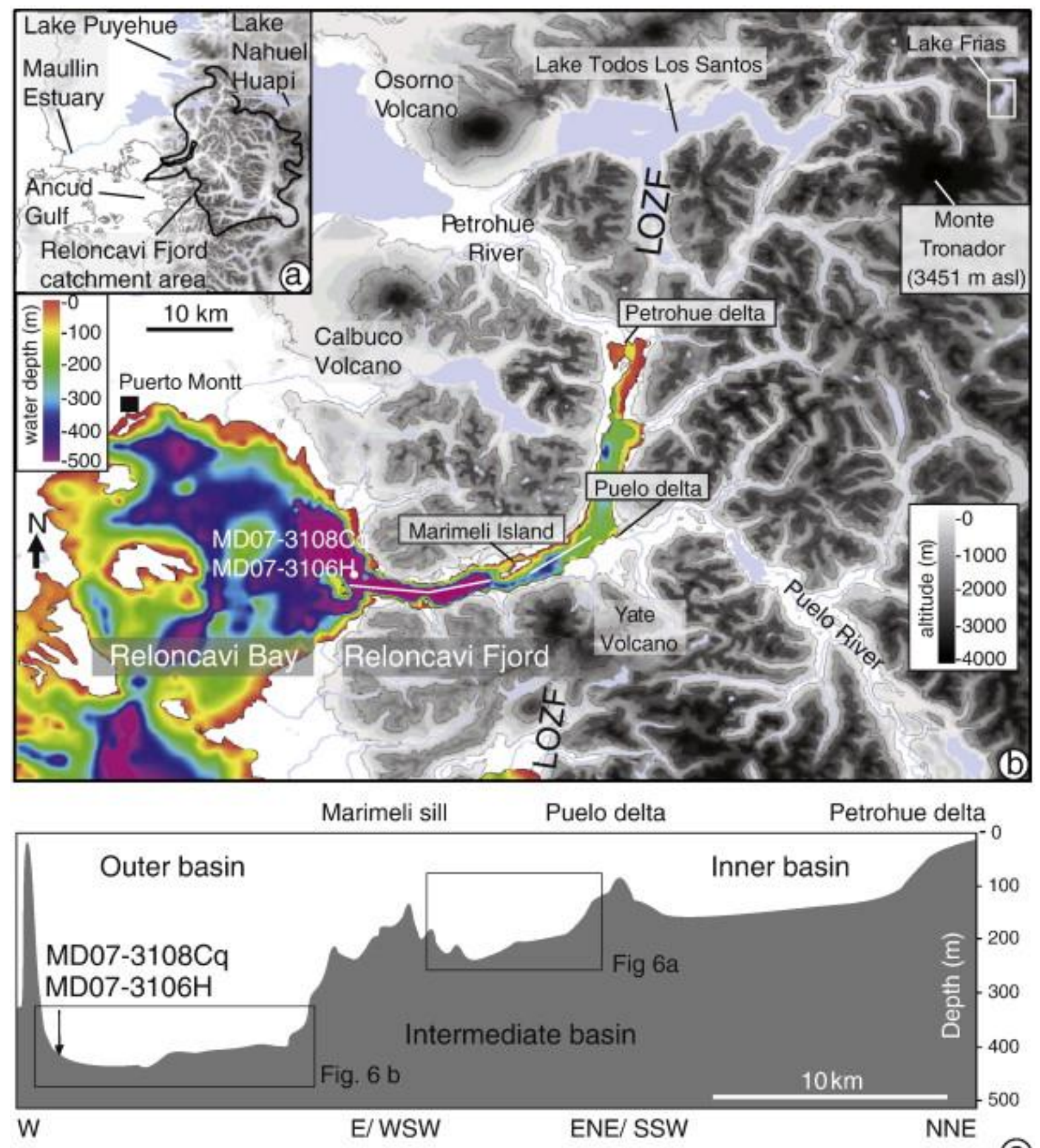

(C)

Fig. 3. Digital elevation model of the topography in Northern Patagonia (upper panel - a) illustrating the size of Reloncavi Fjord catchment area (black line) and the location of lakes Nahuel Huapi (Argentina) and Puyehue (Chile) together with the Maullin River estuary (Chile) discussed in the text. Detailed digital elevation model of the topography surrounding Reloncavi Fjord and Bay and the bathymetry of these sub-basins (middle panel - b). Also illustrated are cores MD07-3108 Cq and MD3106H sampling site, as well as the Yate, Calbuco and Osorno volcanoes, lakes Frias (Argentina) and Todos Los Santos (Chile), and the LOFZ discussed in the text. The bathymetric profile along the axis of the fjord (lower panel $-c$ ) from the Petrohue delta to the outer basin also reveals the presence of sub-basins, deltas and sills of glacial origin. The location of the seismic profiles presented in Fig. 6 is also illustrated. 


\section{a}

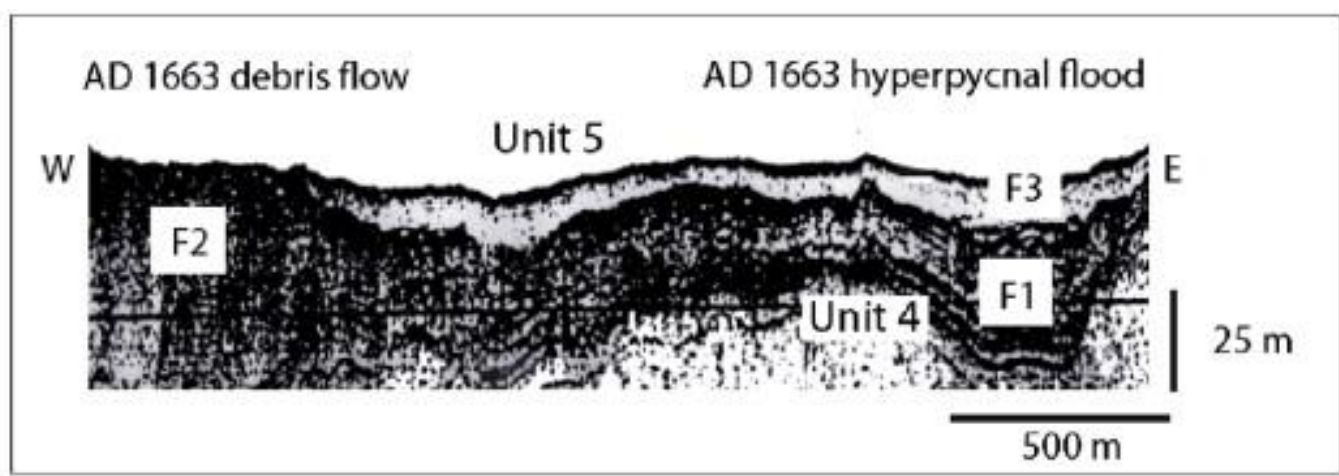

b

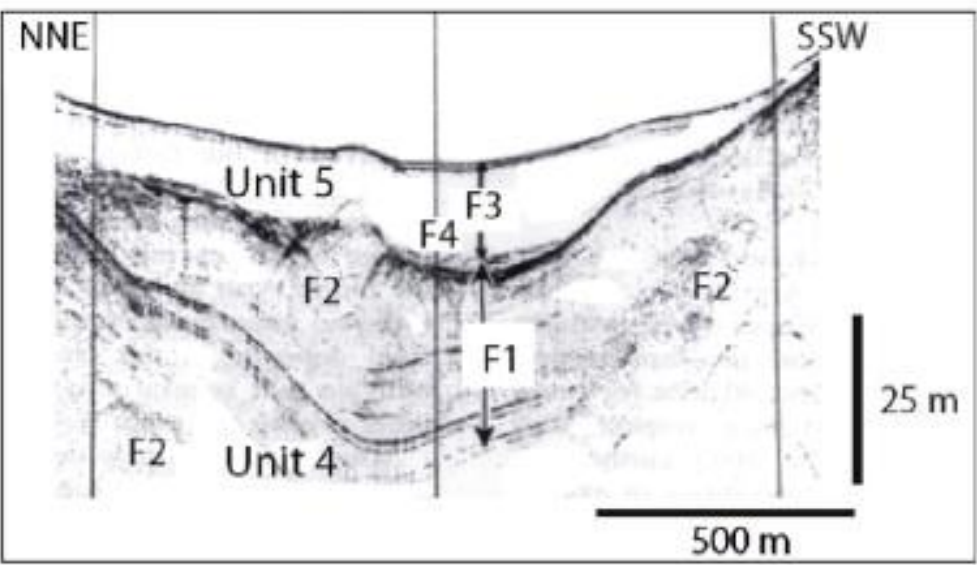

C

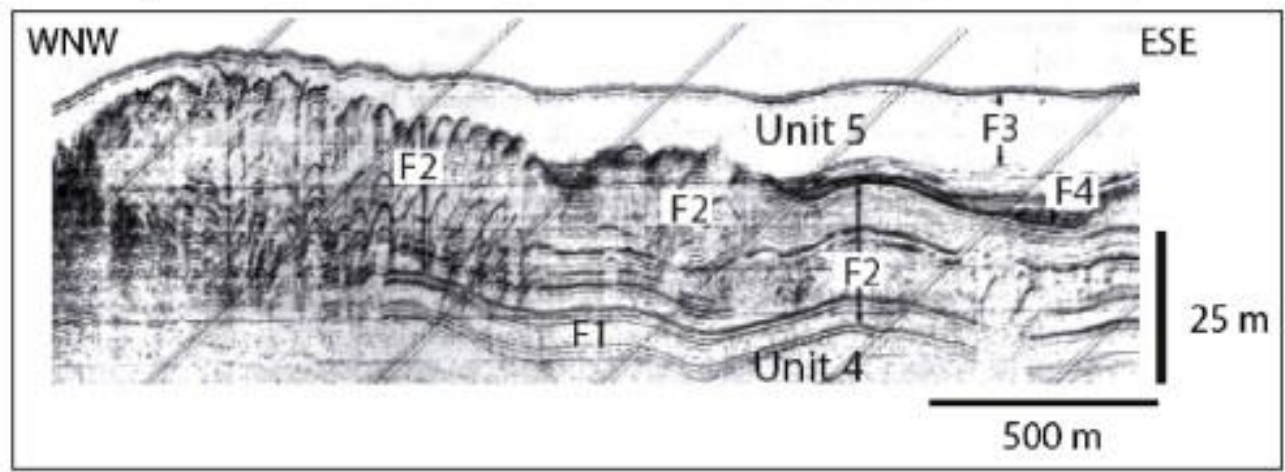

d

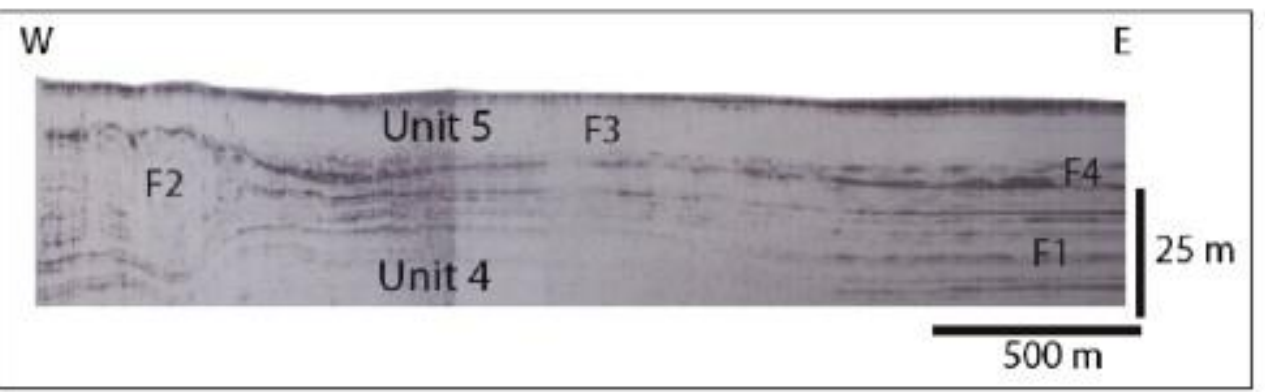

Fig. 4. Selection of four seismic reflection profiles from the inner basin of the Saguenay Fjord (see Fig. 2 for location) (4a, modified from Perret et al., 1995), in the distal part of the inner basin (4b and 4c, modified from Syvitski and Schafer, 1996) and in the middle of the inner basin (4d). Seismic units 4 and 5 of Syvitski and Praeg (1989) and Syvitski and Schafer (1996) are illustrated together with seismic facies F1, F2, F3 and F4 discussed in the text (this study). 


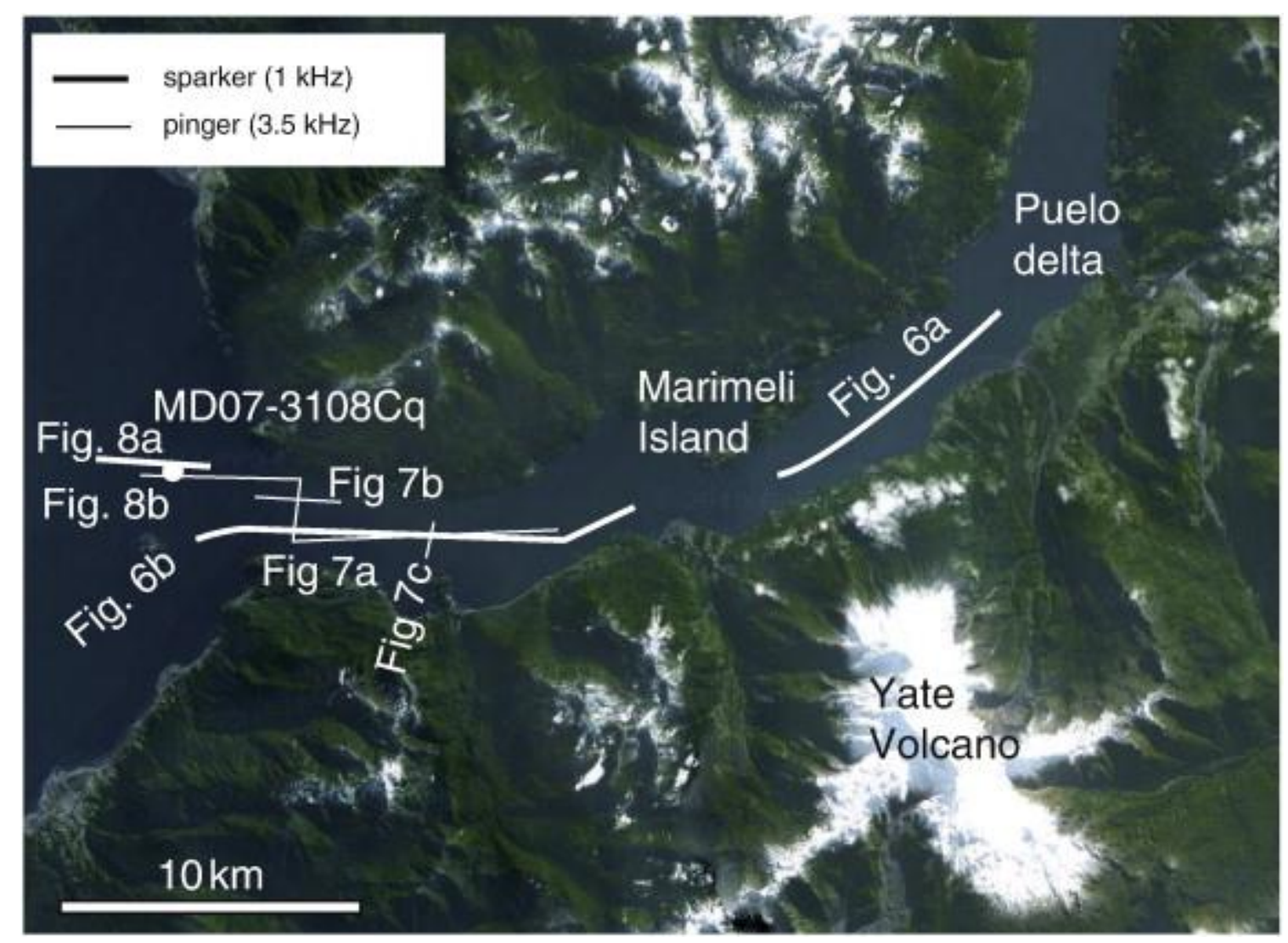

Fig. 5. Location of seismic profiles from the Reloncavi Fjord presented in Fig. 6, Fig. 7 and Fig. 8. Core MD07-3108 Cq sampling site, the Yate Volcano, Puelo delta and Marimeli Island are also shown. 


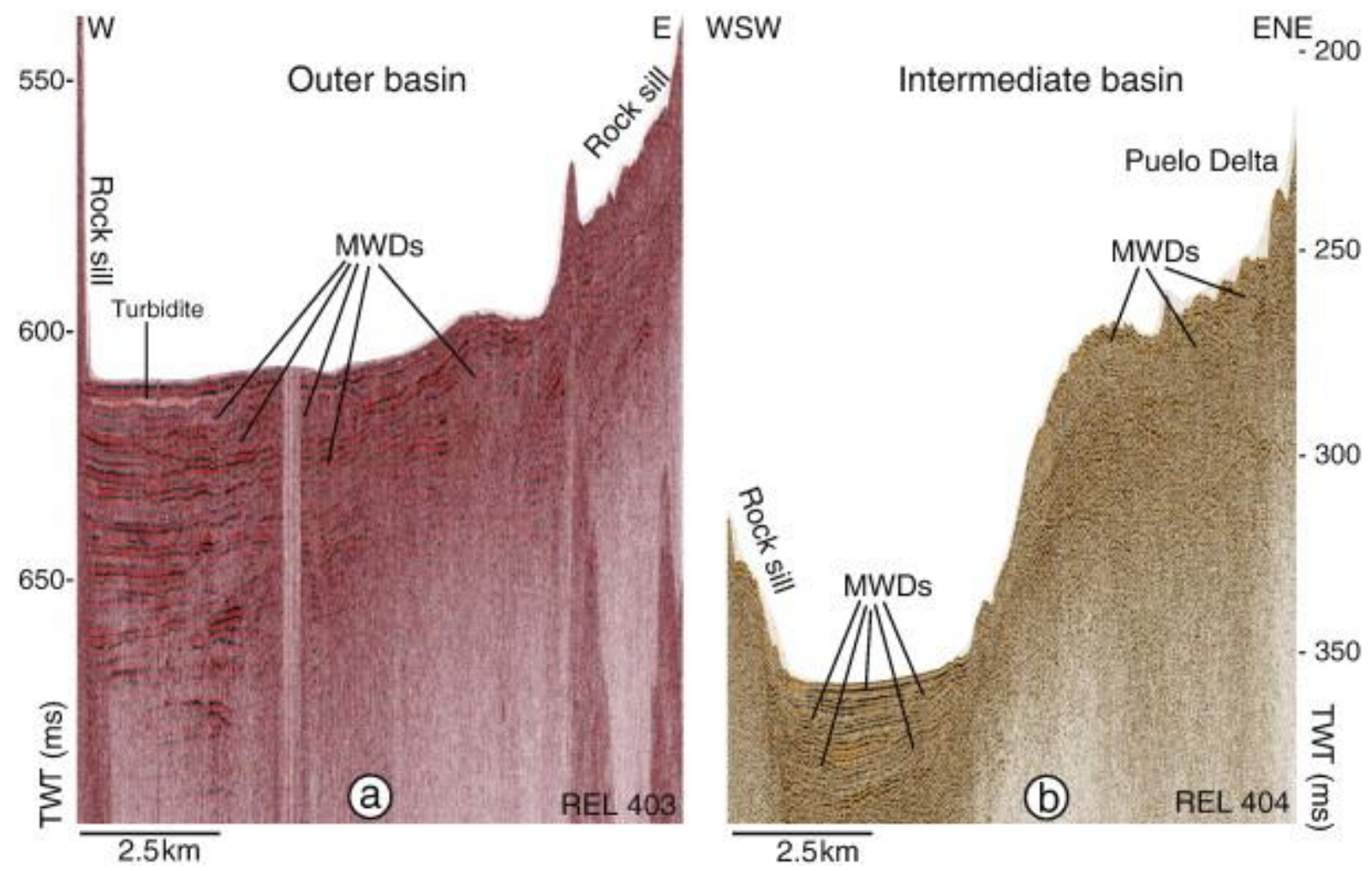

Fig. 6. Sparker ( $1 \mathrm{kHz}$ ) seismic profiles from the outer (a) and intermediate (b) basins of the Reloncavi Fjord illustrating the occurrence of mass wasting deposits (MWDs), rock sills and turbidites. The vertical scales are given in two-way-travel time (TWT). 

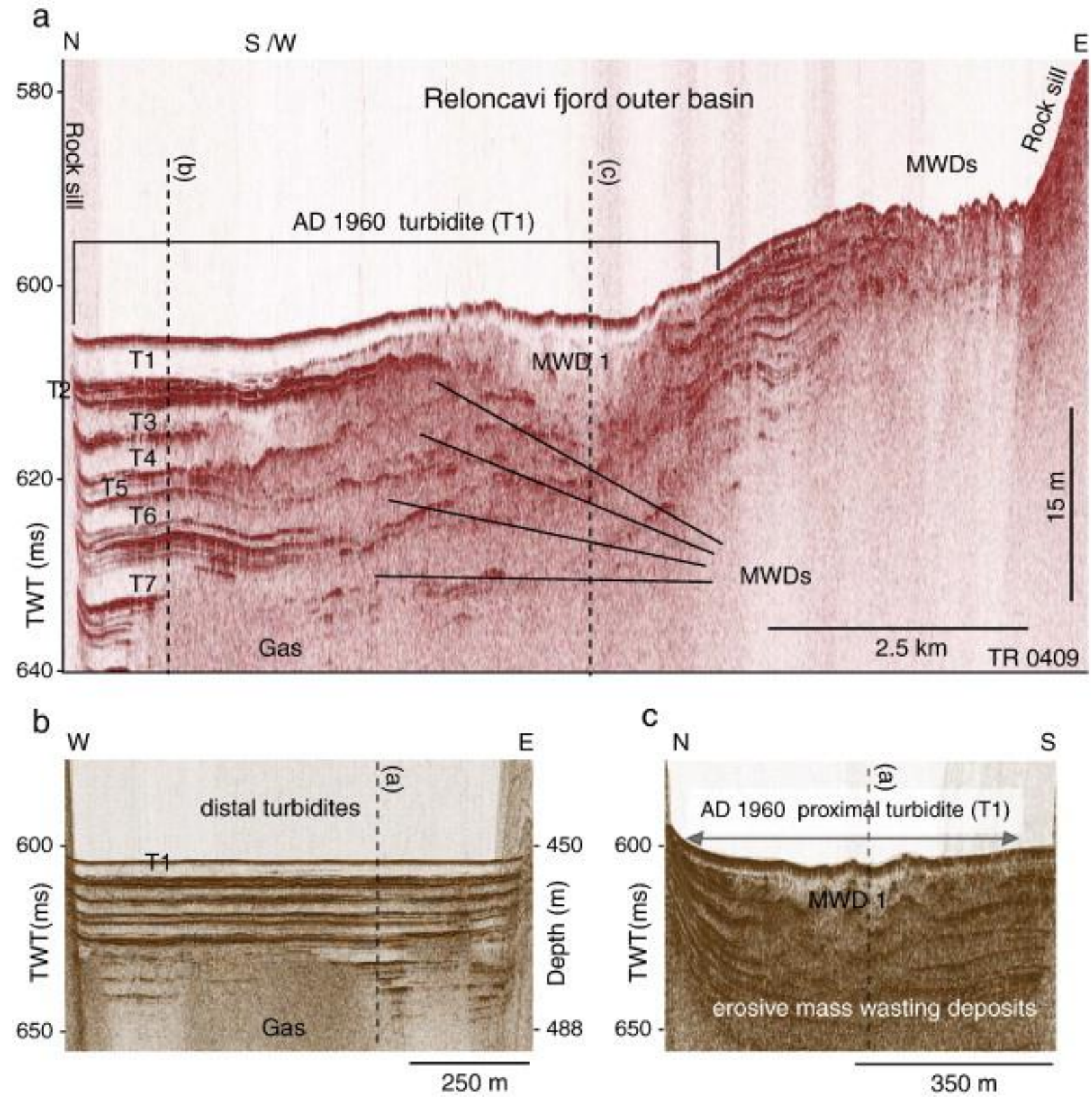

Fig. 7. Selection of pinger $(3.5 \mathrm{kHz})$ seismic profiles from the outer basin of the Reloncavi Fjord illustrating the accumulation of mass wasting deposits (MWDs), seven large turbidites (T1 to T7) and the occurrence of free gas in the sediments. The vertical scale is given in twoway-travel time (TWT) and in meters (assuming a velocity of $1500 \mathrm{~m} \mathrm{~s}^{-1}$ ). Profiles a, b and c intersections are also shown. 

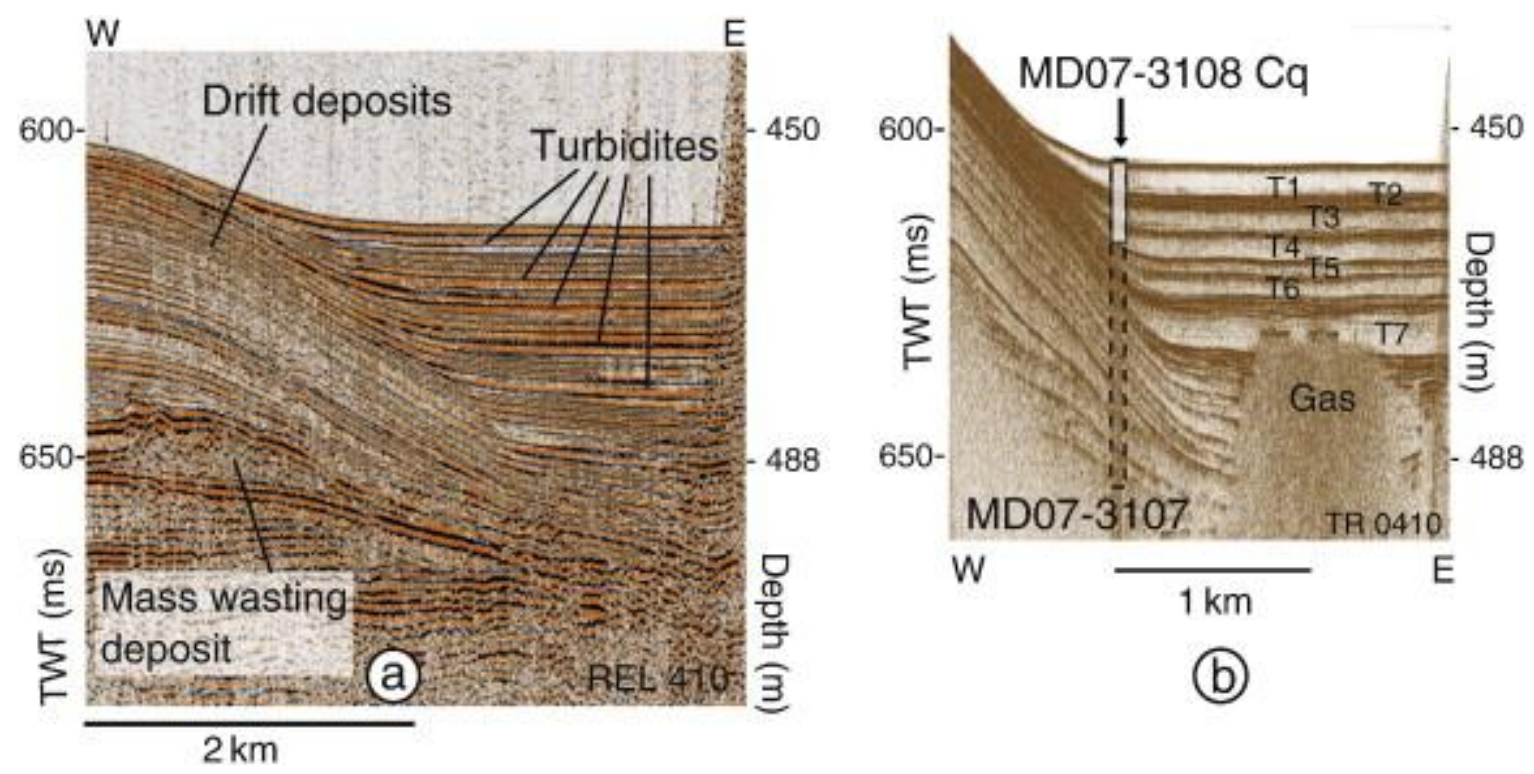

Fig. 8. Selection of seismic profiles in the distal outer basin of the Reloncavi Fjord illustrating the accumulation on sparker (a) and pinger (b) profiles of turbidite deposits stacked in the channel of a drift deposit. The location of cores MD07-3108 CASQ and MD07-3107 is given in (b). The vertical scale is given in two-way-travel time (TWT) and in meters (assuming a velocity of $1500 \mathrm{~m} \mathrm{~s}^{-1}$ ) below the sea surface.

Table 1. Radiocarbon analyses from core MD07-3108 Cq (Reloncavi Fjord). The conventional age $\left({ }^{14} \mathrm{C}\right.$ yr BP) is reported at $1 \sigma$, whereas the calibrated ages (cal BP or AD) were derived using the $2 \sigma$ range.

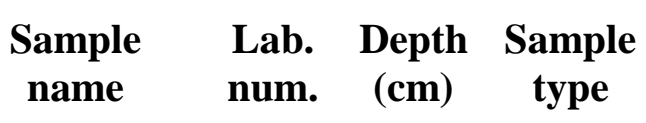

MD07-3108- Poz$444 \quad 20917$

MD07-3108- Poz-

562

444 Wood

562 Shell

\begin{tabular}{|c|c|c|}
\hline $\begin{array}{c}\text { Age } \\
\left({ }^{14} \mathrm{C} \text { yr }\right. \\
\text { BP })\end{array}$ & $\Delta \mathbf{R}$ & $\begin{array}{c}\text { Calibrated } \\
\text { age } \\
(\text { cal BP) }\end{array}$ \\
\hline
\end{tabular}

$1220 \pm 30-1159 \pm 60$

$791 \pm 60$

$810 \pm 30 \quad 0 \quad 475 \pm 31$

$1475 \pm 31$ 


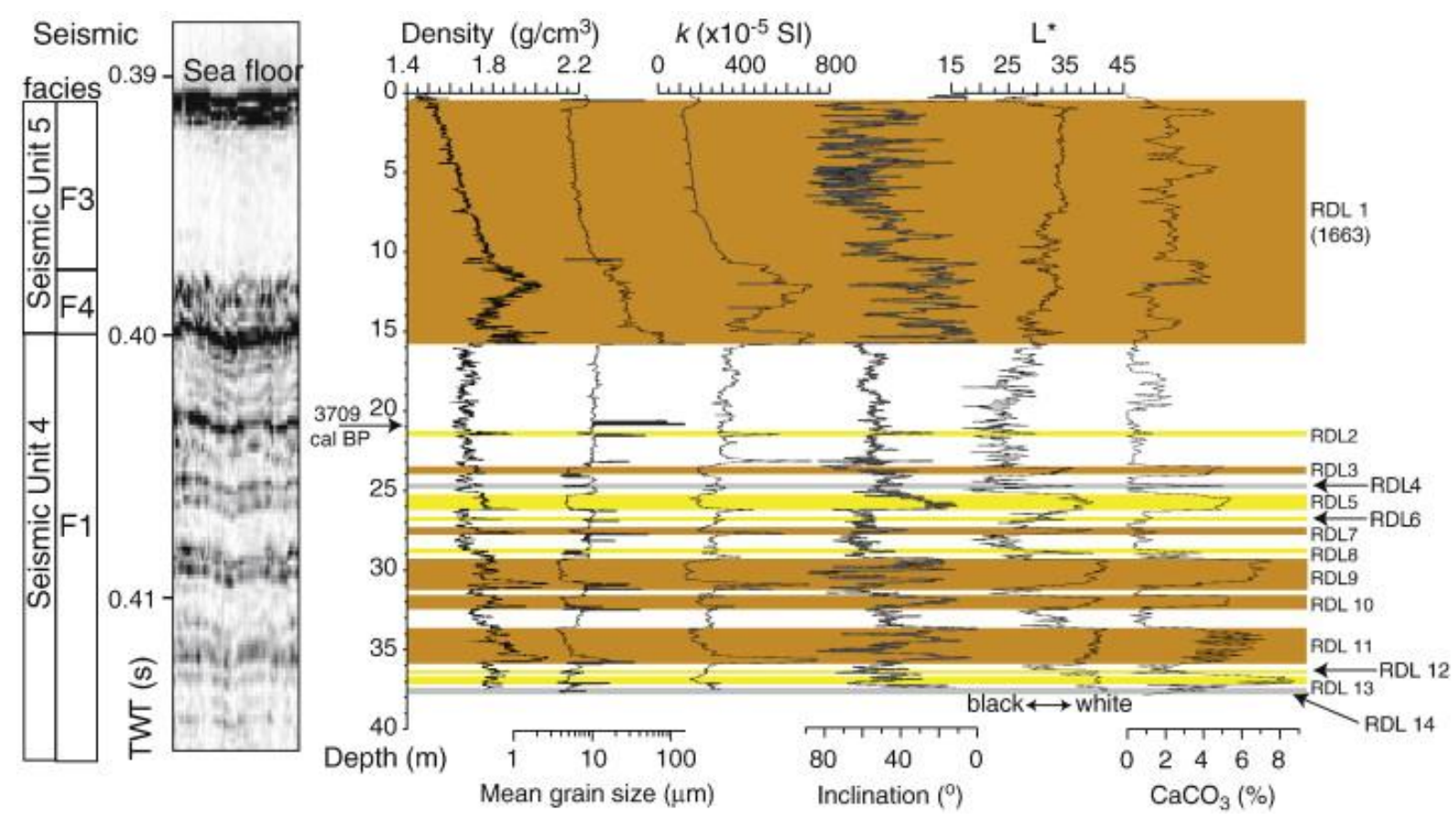

Fig. 9. Correlation of the seismic facies and Rapidly Deposited Layers (RDLs) identified the sampling site of core MD99-2222 in the Saguenay Fjord. Two types of RDLs are distinguished (turbidites in yellow and turbidites capped by a hyperpycnite in orange) based on the physical properties (bulk density, diffuse spectral reflectance $\left(\mathrm{L}^{*}\right)$, grain size), carbonate content $\left(\mathrm{CaCO}_{3}\right)$ and paleomagnetic data (low-field volumetric magnetic susceptibility ( $k$ ) and inclination). 

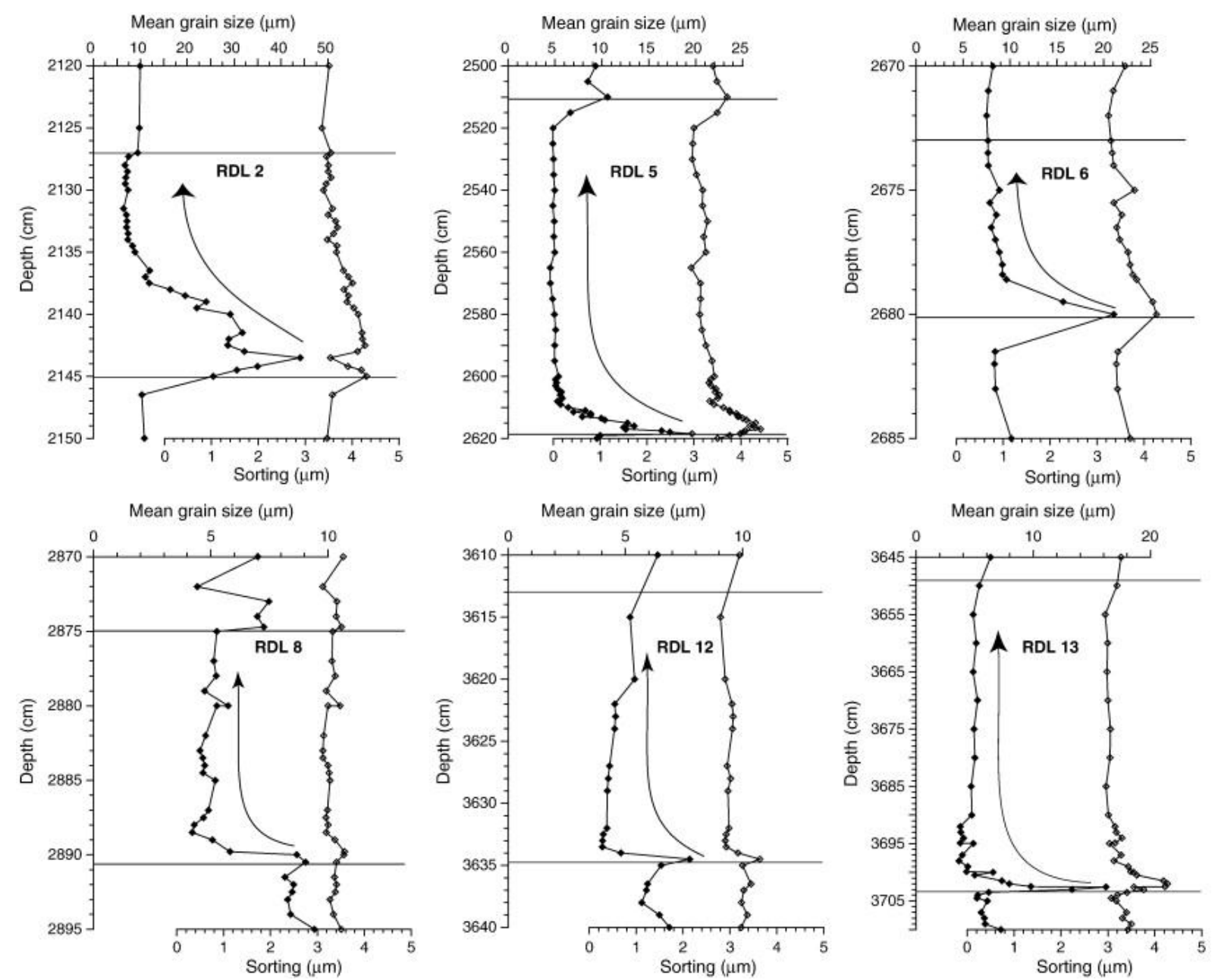

Fig. 10. Detailed grain size signature of RDLs (classical turbidites) from the Saguenay Fjord showing a fining-upward trend for each RDL. 
Table 2. Characteristics and age of the rapidly deposited layers (RDL) from the Saguenay and Reloncavi Fjords.

\section{Trigger mechanism}

Estimated age (cal BP), or (AD) when

reported

\section{Layer $\begin{gathered}\text { Thickness } \\ (\mathrm{cm})\end{gathered} \quad$ Type of deposit}

Core MD99-2222 (Saguenay Fjord)

\begin{tabular}{|c|c|c|}
\hline RDL 1 & 1500 & $\begin{array}{l}\text { Basal } \\
\text { turbidite + overlying } \\
\text { hyperpycnite }\end{array}$ \\
\hline RDL 2 & 17 & Turbidite \\
\hline RDL 3 & 61 & $\begin{array}{l}\text { Basal } \\
\text { turbidite + overlying } \\
\text { hyperpycnite }\end{array}$ \\
\hline RDL 4 & 7 & Homogenous gray layer \\
\hline RDL 5 & 109 & Turbidite \\
\hline RDL 6 & 7 & Turbidite \\
\hline RDL 7 & 36 & $\begin{array}{l}\text { Basal } \\
\text { turbidite + overlying } \\
\text { hyperpycnite }\end{array}$ \\
\hline RDL 8 & 16 & Turbidite \\
\hline RDL 9 & 190 & $\begin{array}{l}\text { Basal } \\
\text { turbidite + overlying } \\
\text { hyperpycnite }\end{array}$ \\
\hline & & Basal \\
\hline
\end{tabular}

RDL $10 \quad 81$$$
\text { turbidite + overlying }
$$$$
\text { hyperpycnite }
$$$$
\text { Basal }
$$

RDL $11 \quad 229$

turbidite + overlying

hyperpycnite

RDL $12 \quad 22$

Turbidite

RDL $13 \quad 54$

Turbidite

RDL 14 Not fully

upper part of a turbidite
Likely the homogenous

Earthquake and

subsequent hyperpycnal flow

Earthquake

Earthquake and

subsequent

hyperpycnal flow

Unknown

Earthquake

Earthquake

Earthquake and

subsequent

hyperpycnal flow

Earthquake

Earthquake and

subsequent

hyperpycnal flow

Earthquake and

subsequent

hyperpycnal flow

Earthquake and

subsequent

hyperpycnal flow

Earthquake

Earthquake

Unknown

Core MD07-3108 Cq (Reloncavi Fjord)

RDL 1219

Turbidite

Earthquake

RDL 248

Turbidite

Earthquake

Tsunami 6

layer

Sand layer

RDL 3185

Turbidite

RDL 4162
Tsunami

Earthquake

Earthquake
7150

1960 AD

1837 AD

1663 AD

3700

4200

4600

4900

5150

5250

5650

5750

5950

6850

7000

1575 AD

1575 AD

$\sim 1400 \mathrm{AD}$ 


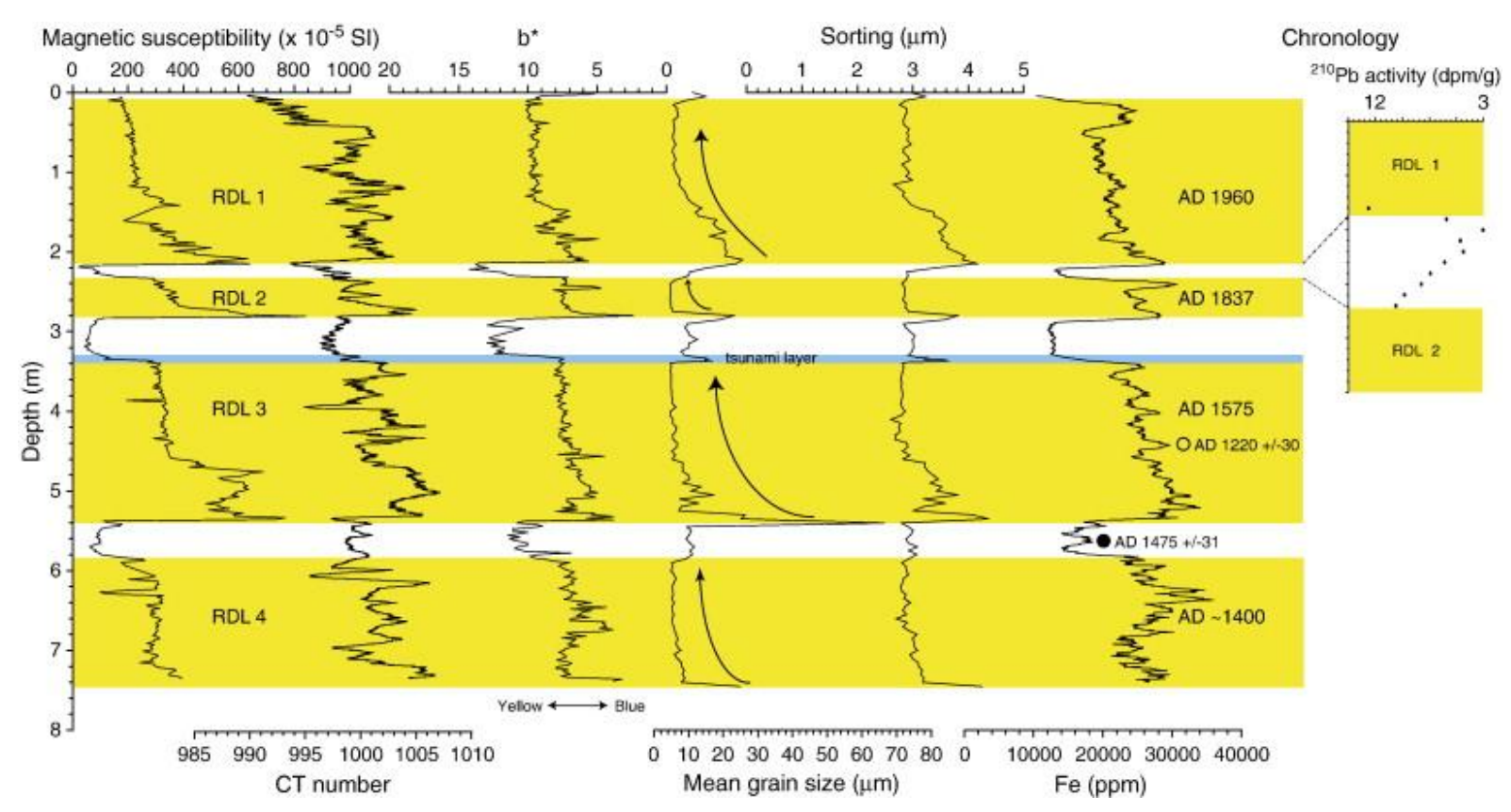

Fig. 11. RDLs in core MD07-3108 Cq. These layers were identified based on the physical properties (low-field volumetric magnetic susceptibility (k), CT number (primarily reflecting bulk density), diffuse spectral reflectance ( $\left.b^{*}\right)$, grain size) and geochemistry (Fe content). Two types of RDLs are distinguished (four turbidites in yellow and a tsunami layer in blue). Ages obtained on a shell (black circle) and a wood fragment (white circle) are also illustrated. 

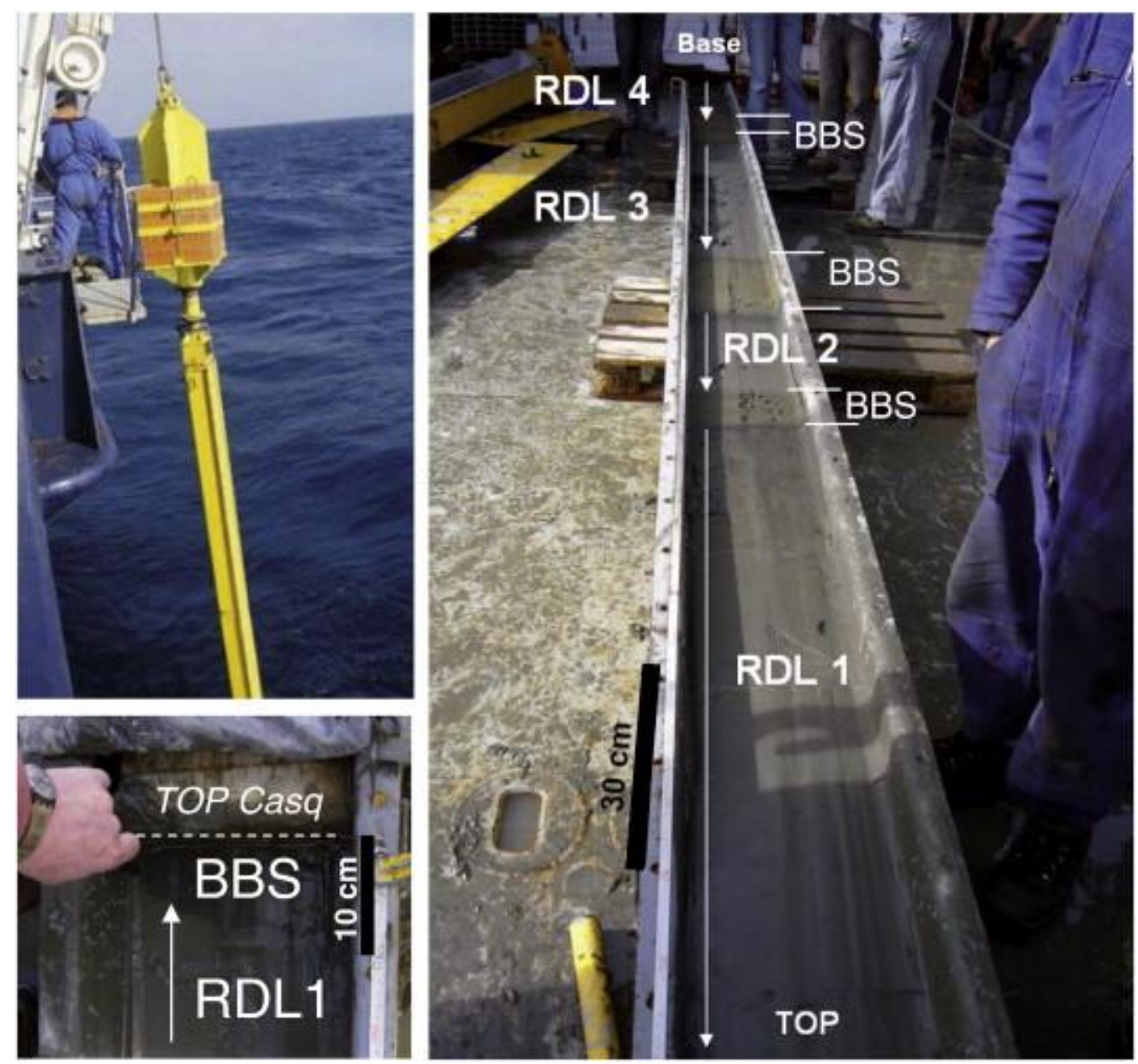

Fig. 12. Pictures of the Calypso CASQ corer on board the R/V Marion Dufresne II (left) and of core MD07-3108 Cq just after being opened on the deck (right). The Rapidly Deposited Layers (RDLs) are clearly contrasting with the Bioturbated Background Sediments (BBS). A detailed picture of the top of core MD07-3108 Cq before sampling reveals that RDL 1 is covered by less than $10 \mathrm{~cm}$ of BBS. A similar thickness of hemipelagic sediments was also observed in the companion surface core (see Fig. 15). 


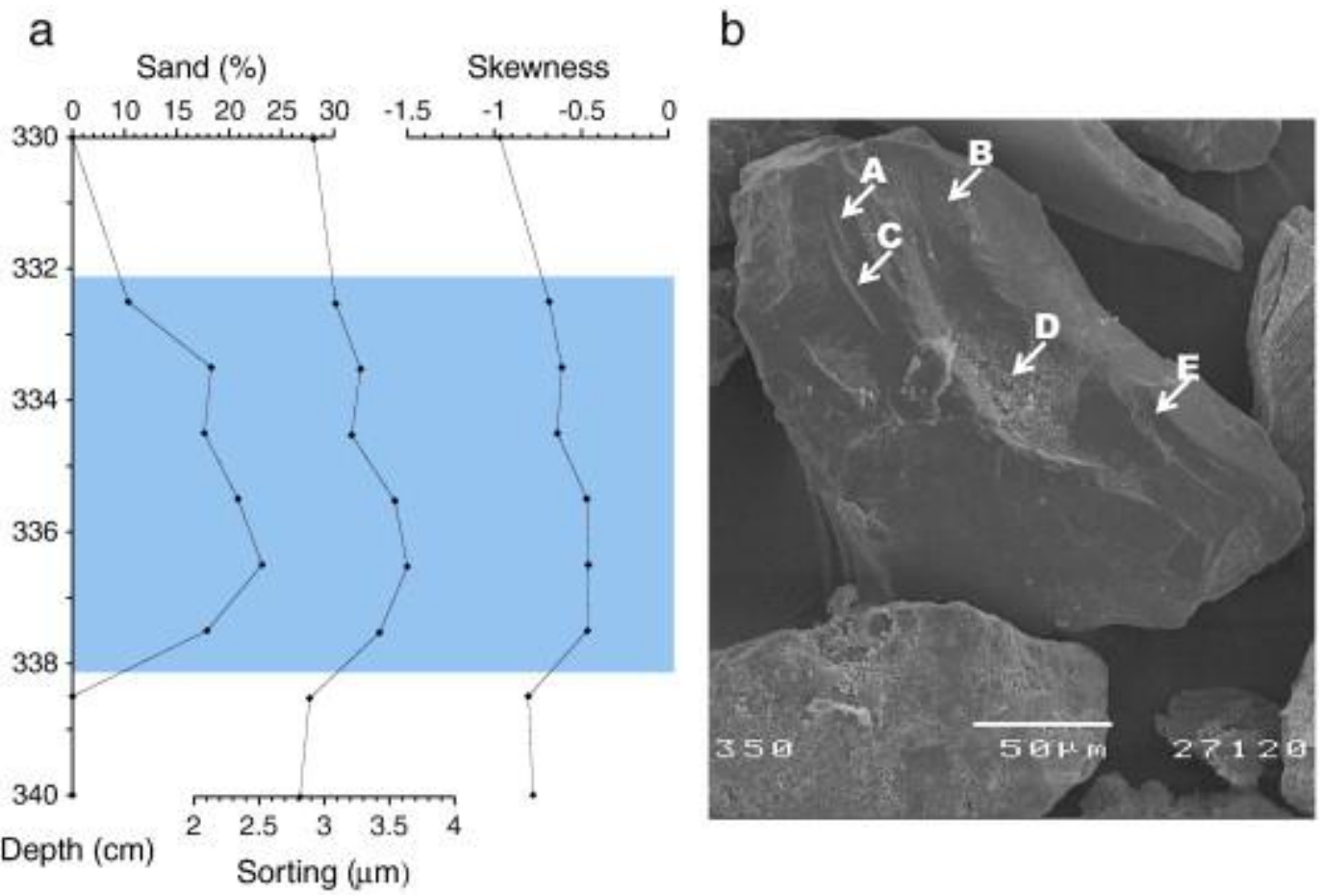

Fig. 13. Grain size signature of the sand layer overlying RDL 3 in the Reloncavi Fjord (a) and Scanning Electron Microscope (SEM) image of a typical quartz grain (b) from this layer characterized by dissolution features (A), fresh surfaces (B), percussion marks (C), adhering particle (D) and fresh surface $(E)$. 

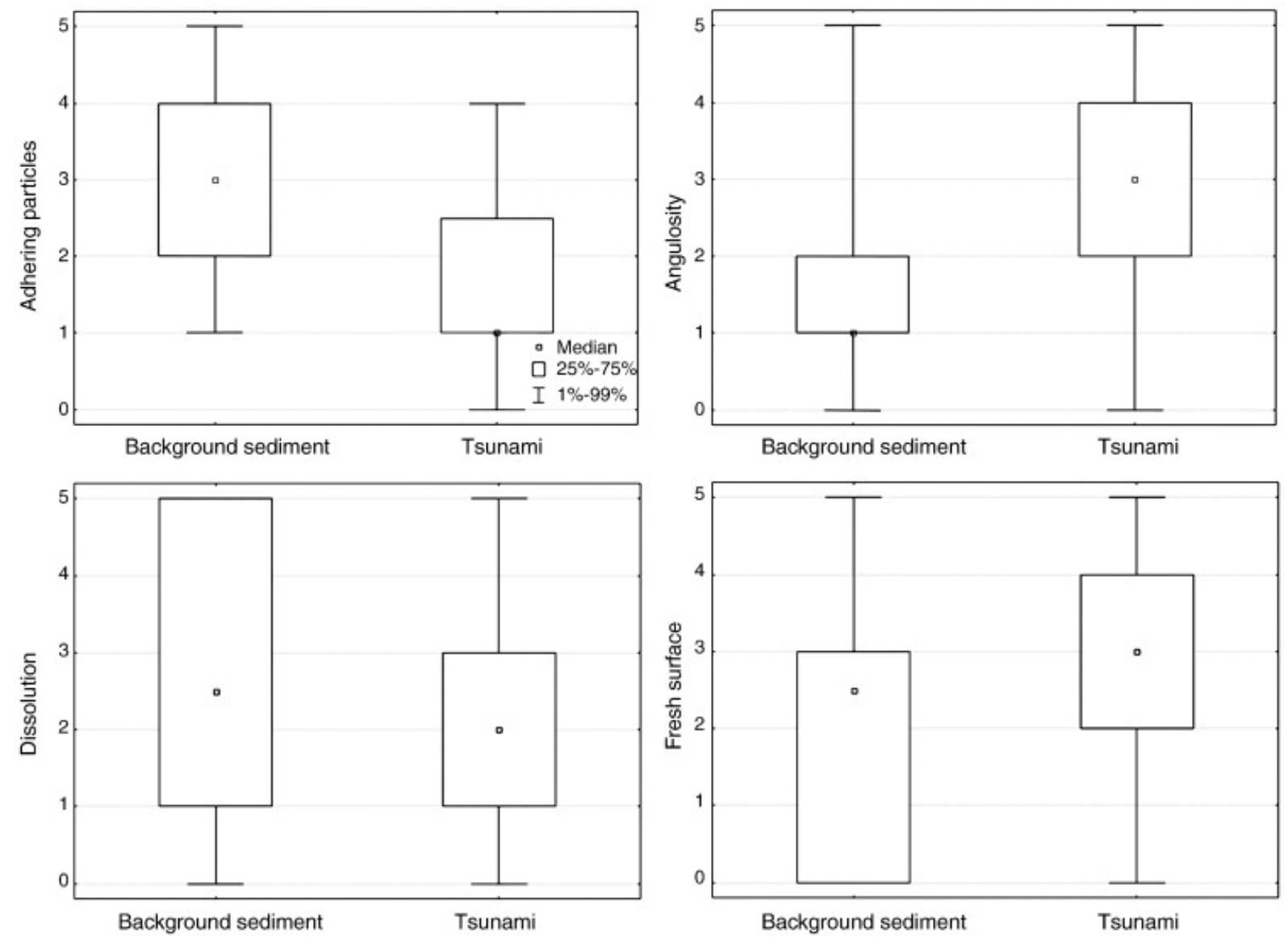

Fig. 14. Box plot diagrams comparing the range of microtextural signatures detected in grains from the possible tsunami deposit ( $n=32$ grains) and background sediments ( $n=18$ grains). 


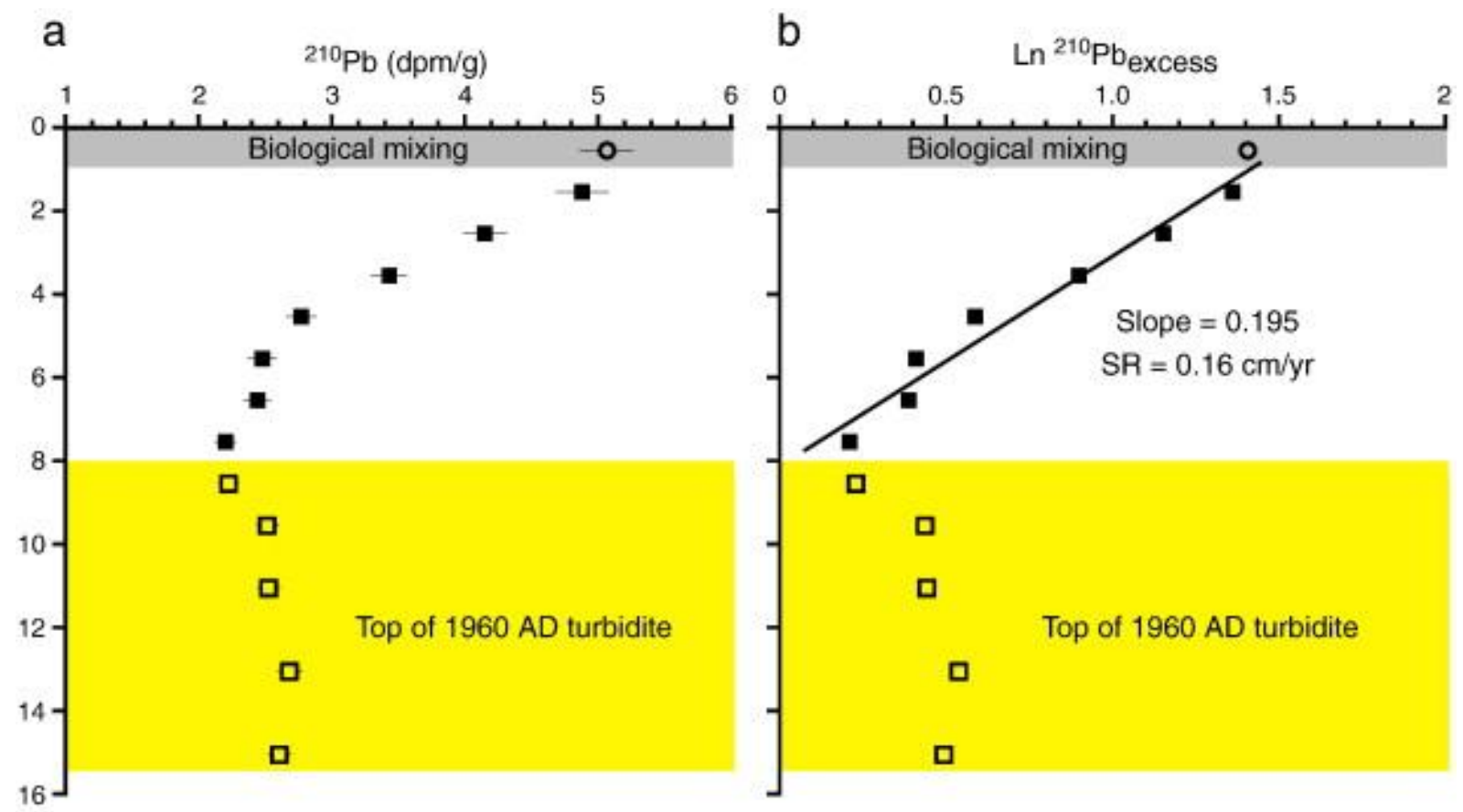

Mean depth $(\mathrm{cm})$

Fig. 15. a) ${ }^{210} \mathrm{~Pb}$ activity and b) derived sedimentation rate (SR) for core MD07-3106H. Biological mixing occurs in the upper $\sim 1 \mathrm{~cm}$, followed by a clear exponential decrease of the ${ }^{210} \mathrm{~Pb}$ activity until the top of the 1960 AD turbidite. The supported ${ }^{210} \mathrm{~Pb}$ value was estimated from the average ${ }^{210} \mathrm{~Pb}$ activity values at the base of the core $(0.98 \pm 0.06 \mathrm{dpm} / \mathrm{g})$ and is very similar to the one obtained in a nearby core from the Gulf on Ancud (Rebolledo et al., 2011). The sedimentation rate in (b) was calculated from the slope of the linear regression using a constant initial concentration model. 
Direct impact of the AD 1663 earthquake

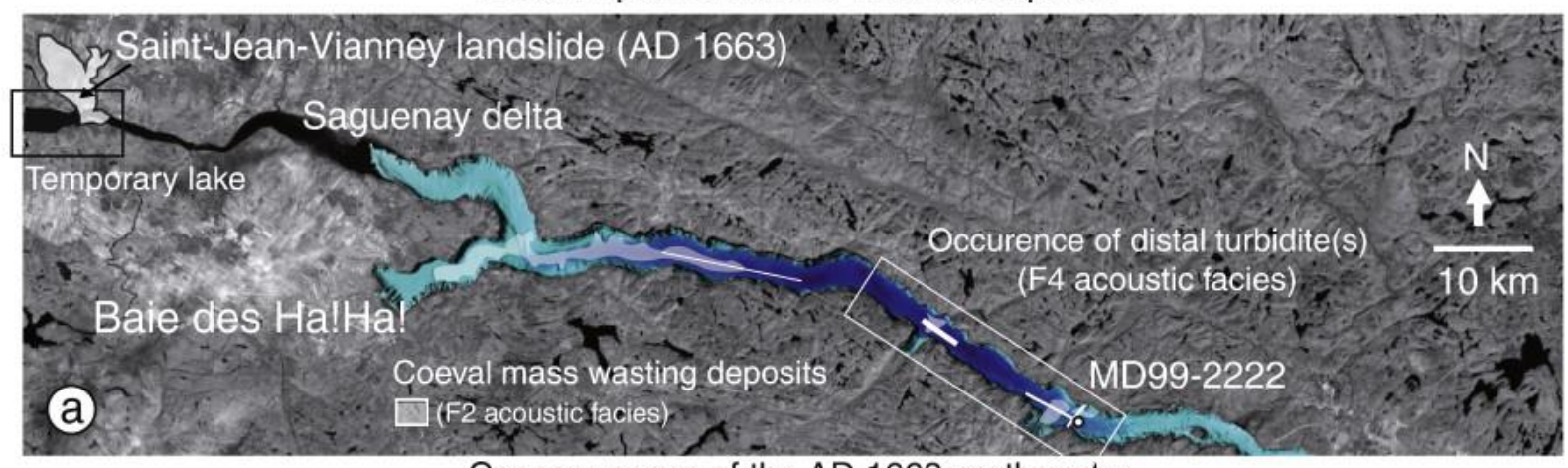

Consequences of the AD 1663 earthquake

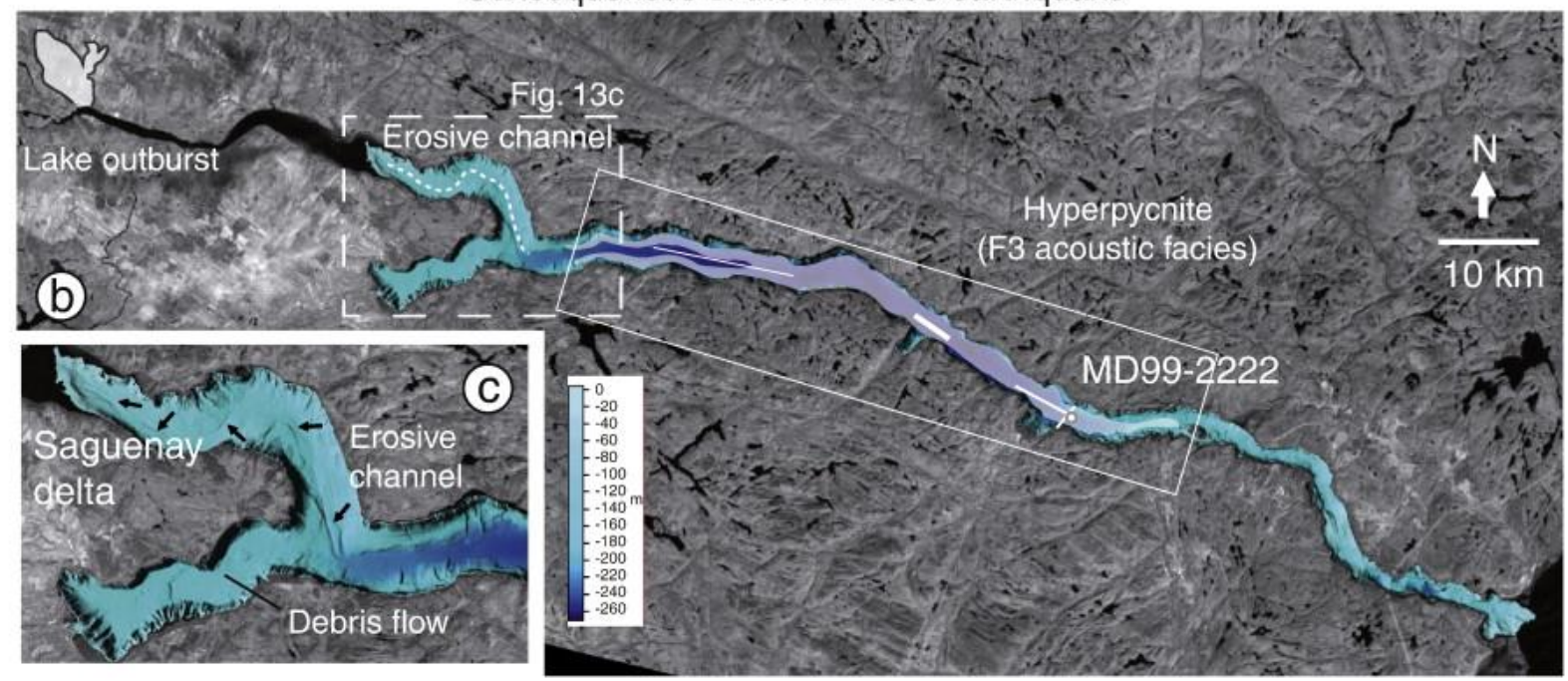

Fig. 16. Synthetic map of the direct impact of AD 1663 earthquake (a) and of its consequences (b) in the Saguenay Fjord. A detailed view of the Saguenay Fjord delta multibeam bathymetry (c) also reveals the morphology of an erosive channel (black arrows) and of flow and slump deposits in the Baie des Ha!Ha! documented by Urgeles et al. (2002) and associated to the AD 1663 earthquake by Locat (2011). Modified from Mulder et al. (2003), after [Praeg and Syvitski, 1991], [Syvitski and Schafer, 1996], [Urgeles et al., 2002] and [Lévesque et al., 2006]. 


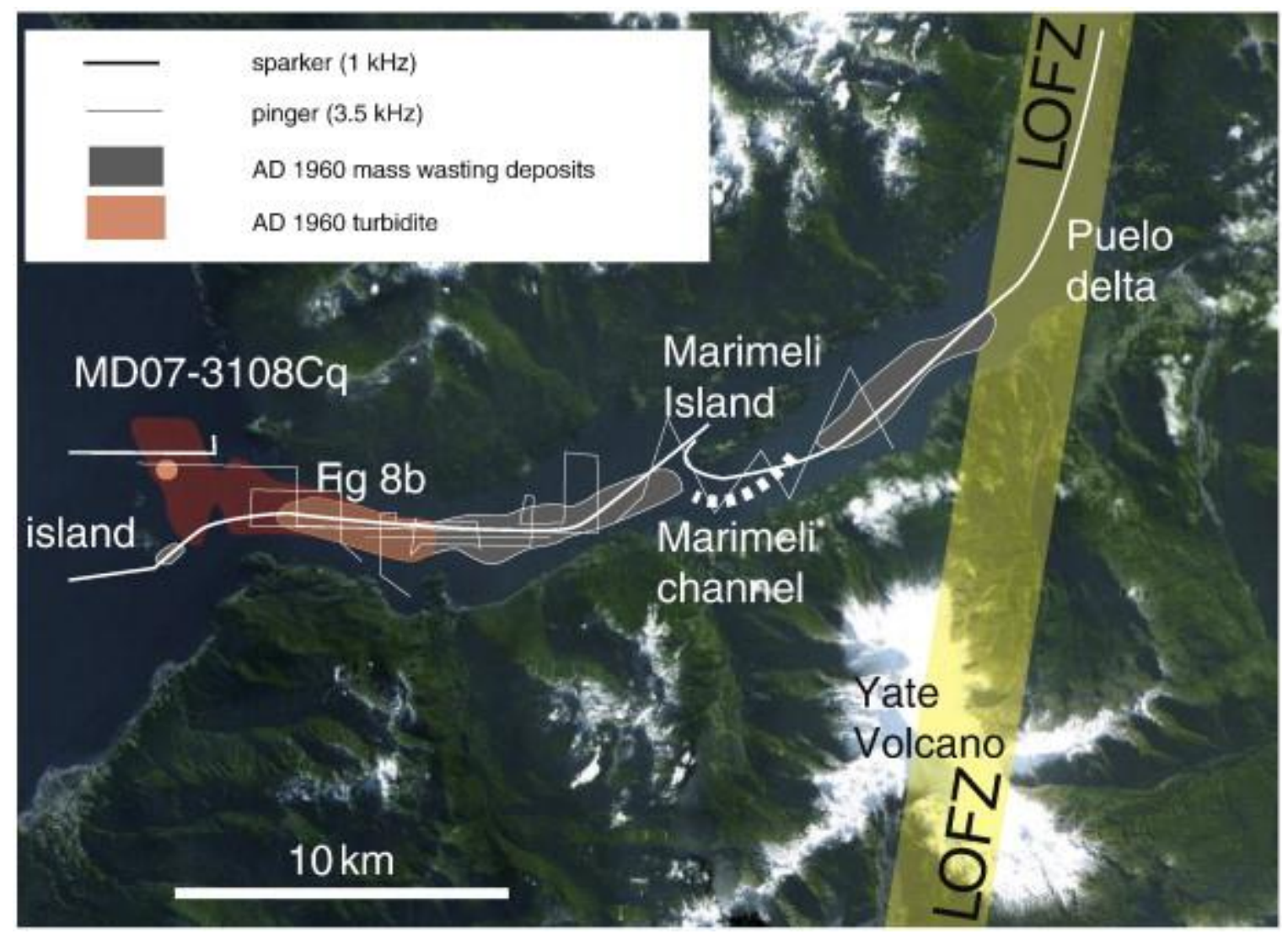

Fig. 17. Synthetic map of the direct impact of AD 1960 earthquake in Reloncavi Fjord. Mass wasting deposits in the outer basin are distally developing into a large turbidite. These mass wasting deposits are originating from the Puelo delta and passed into the outer basin through the Marimelli channel. Gravity reworking along the Puelo delta was probably triggered by co-seismic movements along the Liquiñe-Ofqui Fault Zone (LOFZ) as discussed in the text. 